\title{
WATER AVAILABILITY, USE, AND ESTIMATED FUTURE WATER DEMAND IN THE UPPER DUCK RIVER BASIN, MIDDLE TENNESSEE
}

BY SUSAN S. HUTSON

U.S. GEOLOGICAL SURVEY

Water-Resources Investigations Report 92-4179

Prepared in cooperation with the UPPER DUCK RIVER DEVELOPMENT AGENCY and the TENNESSEE STATE PLANNING OFFICE 


\title{
U.S. DEPARTMENT OF THE INTERIOR MANUEL LUJAN, JR., Secretary
}

\author{
U.S. GEOLOGICAL SURVEY \\ DALLAS L. PECK, Director
}

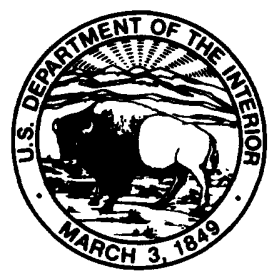

Any use of trade, product, or firm name in this report is for identification purposes only and does not costitute endorsement by the U.S.

Geological Survey.

For additional information write to:

District Chief

U.S. Geological Survey

810 Broadway, Suite 500

Nashville, Tennessee 37203
Copies of this report can be purchased from:

U.S. Geological Survey

Books and Open-File Reports Section

Federal Center, Box 25425

Denver, Colorado 80225 


\section{CONTENTS}

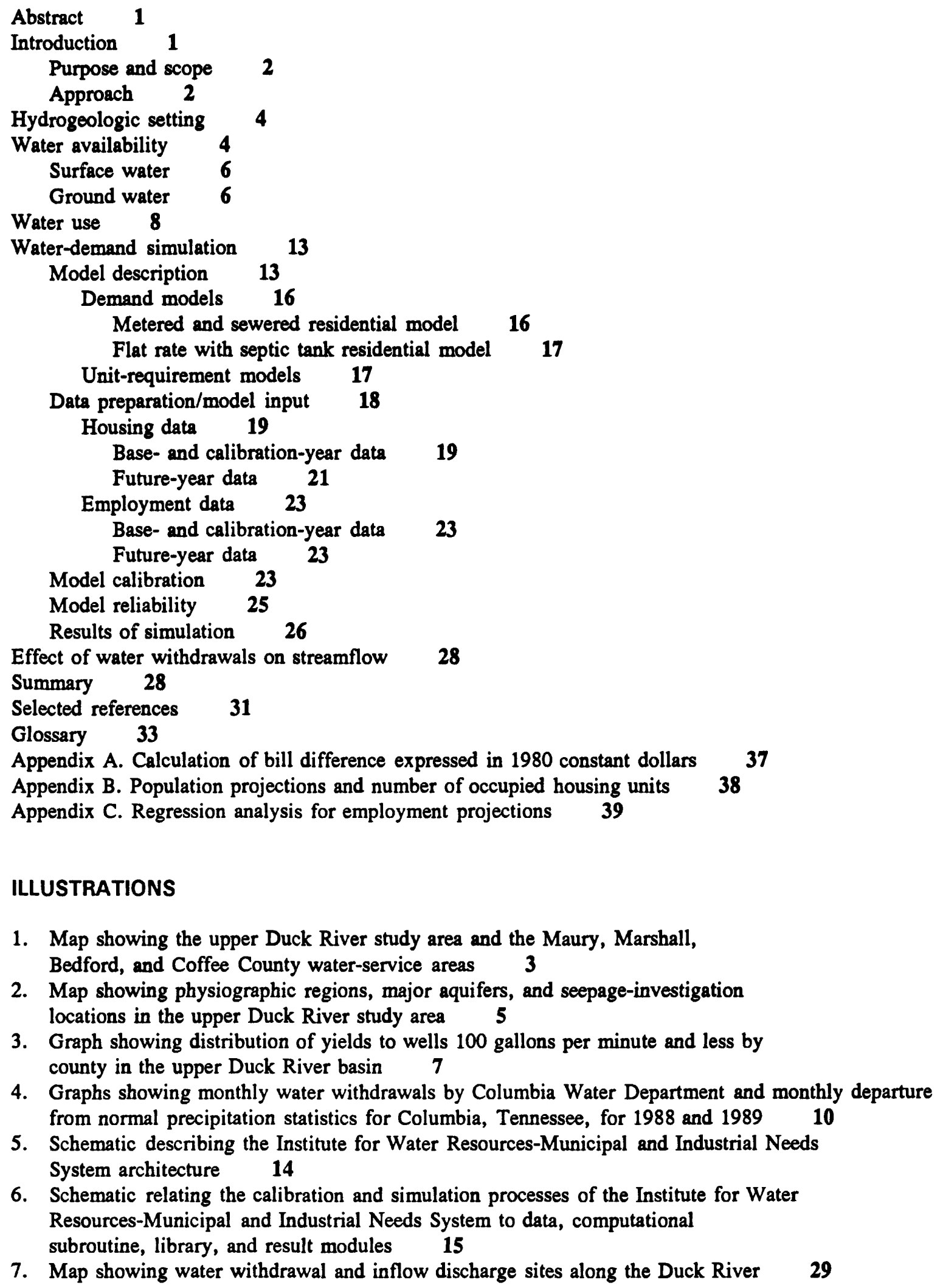

\section{ILLUSTRATIONS}

1. Map showing the upper Duck River study area and the Maury, Marshall, Bedford, and Coffee County water-service areas 3

2. Map showing physiographic regions, major aquifers, and seepage-investigation locations in the upper Duck River study area 5

3. Graph showing distribution of yields to wells 100 gallons per minute and less by county in the upper Duck River basin 7

4. Graphs showing monthly water withdrawals by Columbia Water Department and monthly departure from normal precipitation statistics for Columbia, Tennessee, for 1988 and $1989 \quad 10$

5. Schematic describing the Institute for Water Resources-Municipal and Industrial Needs System architecture 14

6. Schematic relating the calibration and simulation processes of the Institute for Water Resources-Municipal and Industrial Needs System to data, computational subroutine, library, and result modules 15

7. Map showing water withdrawal and inflow discharge sites along the Duck River 


\section{TABLES}

1. Seepage investigations in the upper Duck River basin 8

2. Water-service area withdrawals and number of customer connections 9

3. Average daily water withdrawals by month for major public-supply systems during 1988

4. Seasonal and maximum daily water-use ratios for major public-supply systems for $\mathbf{1 9 8 8}$

5. Public-supply facilities, sources(s) of supply, and water use in the upper Duck River basin, Tennessee 12

6. Public-supply deliveries of water to various water-use sectors during $1989 \quad 13$

7. Socioeconomic parameters input to the Institute for Water Resources-Municipal and Industrial Needs System 16

8. Climatological variables for the water-service areas

9. Number of occupied housing units by type 20

10. Marginal price and bill difference in 1980 dollars for the metered and sewered housing category 21

11. Projected metered and sewered occupied housing units by value range 22

12. Median household income 23

13. Model and calibration coefficients by employment categories for the Institue for Water Resources-Municipal and Industrial Needs System 24

14. Model and calibration constants for the metered and sewered housing models 25

15. Observed and modeled average annual water demand for metered and sewered housing for $1989 \quad 25$

16. Per capita use for the residential sector 26

17. Simulated water demand, upper Duck River basin, by sector for 1989, 1995, 2000, and 2015

18. Effect of water withdrawals and inflow discharges at various locations along the upper Duck River 30

\section{CONVERSION FACTORS}

\begin{tabular}{|c|c|c|}
\hline Multiply & To obtain & By \\
\hline inch (in.) & 25.4 & millimeter \\
\hline foot (ft) & 0.3048 & meter \\
\hline mile (mi) & 1.609 & kilometer \\
\hline acre-foot (acre-ft) & 1,233 & cubic meter \\
\hline cubic foot $\left(\mathrm{f}^{3}\right)$ & 0.02832 & cubic meter \\
\hline cubic foot per second & 0.02832 & cubic meter per \\
\hline second $\left(\mathrm{ft}^{3} / \mathrm{s}\right)$ & 0.64632 & million gallons per day \\
\hline gallon (gal) & 0.003785 & cubic meter \\
\hline gallon per minute (gal/min) & 0.06309 & liter per second \\
\hline gallon per day (gal/d) & 0.003785 & cubic meter per day \\
\hline million gallons (Mgal) & 0.3785 & cubic meter \\
\hline million gallons per day (Mgal/d) & 0.04381 & cubic meter per second \\
\hline
\end{tabular}

Water-use data are shown in million gallons per day and generally are rounded to three significant figures; percentages are rounded to two significant figures. Water-use data may not add to totals shown and percentages may not add to 100 because of rounding of individual values. 


\title{
WATER AVAILABILITY, USE, AND ESTIMATED FUTURE WATER DEMAND IN THE UPPER DUCK RIVER BASIN, MIDDLE TENNESSEE
}

\author{
By Susan S. Hutson
}

\section{Abstract}

Water availability and use during 1989 , and potential future water demands were determined for the upper Duck River basin in Middle Tennessee. The basin includes an area of about 1,700 square miles within the Highland Rim and Central Basin physiographic regions of Tennessee, where limestone rocks of Mississippian and Ordovician age predominate. The Duck River is the principal source of water in the basin, supplying a total of 18.9 million gallons per day (Mgal/d) in 1989 or 93 percent of the municipal supply to the cities of Tullahoma, Manchester, Lewisburg, Shelbyville, Columbia, and several smaller communities. Municipal water use increased 16 percent from 1980 to 1990 (from 18.0 to $20.9 \mathrm{Mgal} / \mathrm{d}$ ). Socioeconomic data and future projections for development in the basin indicate that water demand will continue to increase during the next 25 years. Projections of potential future water demands in the basin for the years 1995, 2000, and 2015 were made using the Institute for Water Resources-Municipal and Industrial Needs System water-use models. The water-use models were calibrated using socioeconomic data for 1989, and were used to estimate water demands for future years. Water demands for year 1995 are estimated to increase 19 percent from 20.4 to $24.3 \mathrm{Mgal} / \mathrm{d}$ ); for year 2000, 39 percent (from about 20.4 to $28.3 \mathrm{Mgal} / \mathrm{d}$ ); and for year 2015,91 percent (from 20.4 to $39.0 \mathrm{Mgal} / \mathrm{d}$ ). Residential water demand for year 2015 is projected to increase by
122 percent, industrial demand by 93 percent, and commercial demand by 82 percent.

Increase in withdrawals from the Duck River throughout the basin would reduce minimum flows at key sites along the river. The reductions would increase through the year 2015 . For an operational flow of 155 cubic feet per second $\left(\mathrm{ft}^{3} / \mathrm{s}\right)$ at Shelbyville, flow at Columbia would be reduced from $136 \mathrm{ft}^{3} / \mathrm{s}$ in 1995 to $120 \mathrm{ft}^{3} / \mathrm{s}$ in 2015 . For a lower operational flow of $120 \mathrm{ft}^{3} / \mathrm{s}$ at Shelbyville, flow at Columbia would decrease from $101 \mathrm{ft}^{3} / \mathrm{s}$ in 1995 to $85.4 \mathrm{ft}^{3} / \mathrm{s}$ in 2015 .

The study also included an overview of the potential for developing the ground-water resources in the basin. Previous studies indicate that ground-water occurrence is irregular and difficult to predict because of the lack of homogeneity among the limestone rocks underlying the basin. Statistical analyses of yields to 5,938 wells in the basin showed that the highest yields occur in Coffee County, and that 75 percent of these wells produced less than 30 gallons per minute. However, measurements of the flow of the tributaries to Duck River show stream channel losses that indicate the potential for development of ground water does exist at specific sites.

\section{INTRODUCTION}

Water demand in the upper Duck River basin in Middle Tennessee increased significantly from 1980 to 
1990. Water for domestic, industrial, and commercial uses from public-supply facilities (municipal use) increased from 18.0 million gallons per day (Mgal/d) in 1980 to $20.9 \mathrm{Mgal} / \mathrm{d}$ in 1990 , or 16 percent. Projected residential, industrial, and commercial developments in the basin suggest that water use will continue to increase. Considerable uncertainty exists among officials from agencies in the basin and from the State of Tennessee whether existing water supplies are adequate to meet additional demands. Long-term projections are needed to determine if the Duck River, the principal source of water in the basin, can supply anticipated future demands.

In 1989, the U.S. Geological Survey (USGS) began an investigation to document trends in water availability and use in the upper Duck River basin. The study also included estimates of future water demands through year 2015. The project was conducted in cooperation with the Upper Duck River Development Agency and the Tennessee State Planning Office. This report summarizes the findings of the investigation.

\section{Purpose and Scope}

The purposes of this report are to:

- Summarize data on surface-water availability in the upper Duck River basin.

- Summarize available data on ground-water resources.

- Summarize the amount of water delivered to the principal customers within each public water-supply service area in the basin.

- Provide estimates of future water demand for the years 1995, 2000, and 2015.

The study area comprises the drainage area of the upper Duck River basin within Bedford, Coffee, Marshall, and Maury Counties, and part of southern Williamson County (fig. 1). The study was limited to this area because water demand from the Duck River will most likely increase as a result of growth in these counties (Steven Parks, Director, Upper Duck River Development Agency, oral commun., 1989).

The investigation included an inventory of water use in the upper Duck River basin, and excludes any assessment of the availability of streamflow for maintaining water quality. Estimates of future water demands in the basin were made with the Institute for Water Resources-Municipal and Industrial Needs (IWR-MAIN) System water-use models designed by Planning and Management Consultants, Ltd. under contract with the U.S Army Corps of Engineers, Institute for Water Resources (U.S. Army Corps of Engineers, 1988). The ground-water availability study was limited to an analysis of existing well records and the measurement of streamflow gains and losses (seepage investigations) along tributaries of the Duck River during two low-flow periods.

\section{Approach}

The following tasks were designed to accomplish the project objectives:

- Surface-water availability was evaluated using existing streamflow records, including periods of minimum flows.

- An inventory of wells in the study area, including a statistical analysis of yields to wells, was performed to analyze the potential for ground-water resources development. Measurements of streamflow during dry weather periods were conducted in two subbasins of the study area to provide additional data on ground-water resources.

- Municipal water use was analyzed using data collected for 1980, 1985, 1989, and 1990.

- The IWR-MAIN water-use models were calibrated for the study area using demographic and economic data for 1989. The calibrated models were used to estimate municipal water demands for the years 1995, 2000, and 2015. 

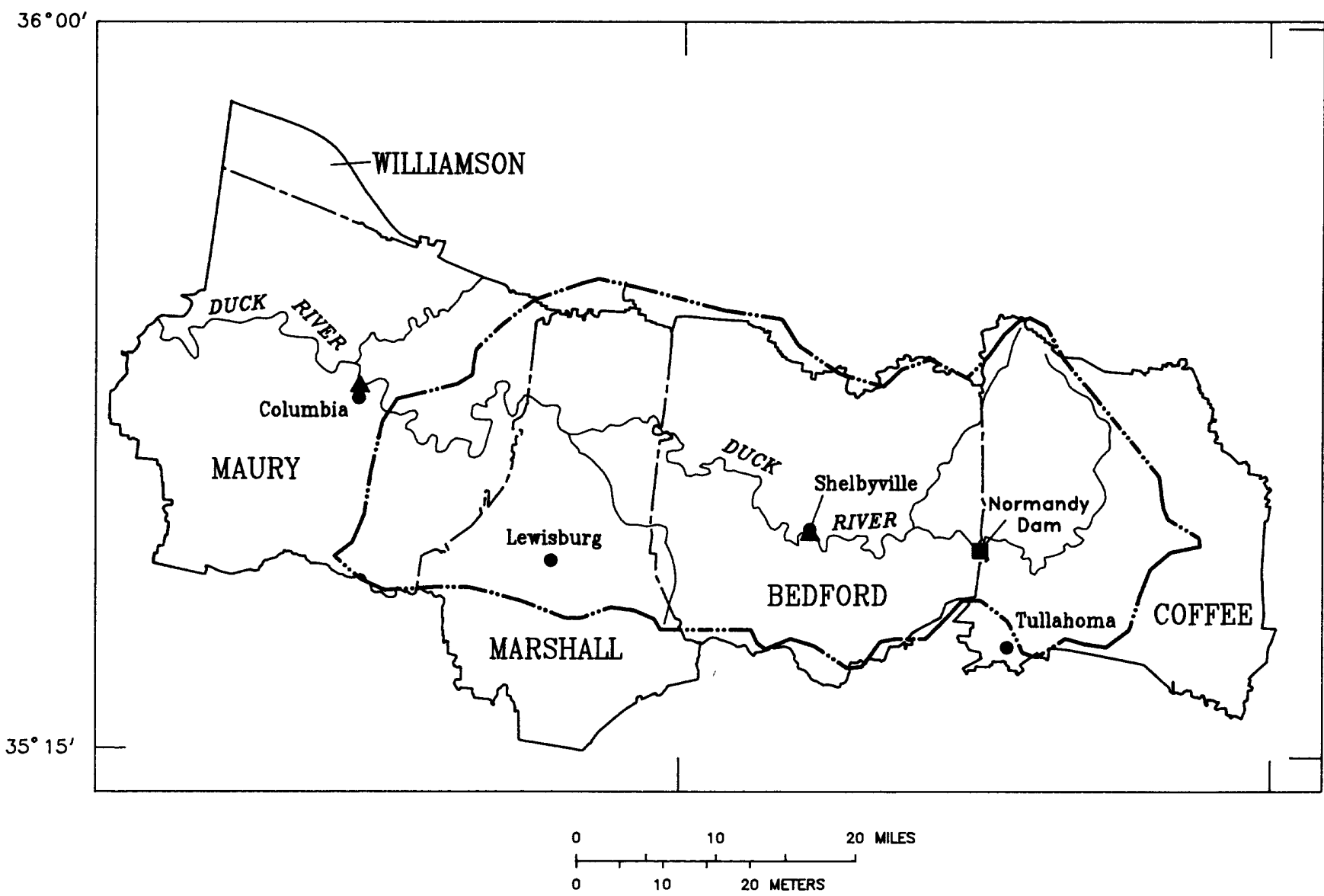

EXPLANATION
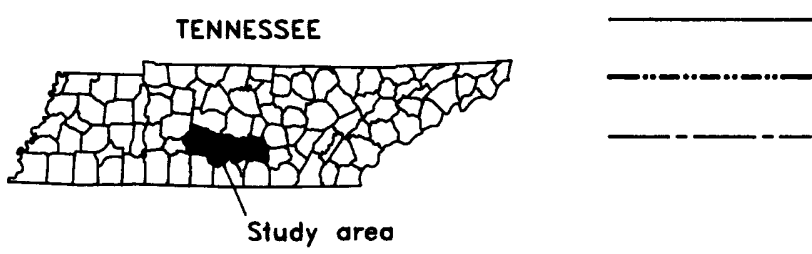

STUDY-AREA BOUNDARY

UPPER DUCK RIVER BASIN BOUNDARY

WATER-SERVICE-AREA BOUNDARY--Each county water-service area is consistent with that county's political boundary, except for the

Maury County water-service area that includes part of southern Williamson County

A CONTINUOUS STREAMFLOW-GAGING STATION

Figure 1. Upper Duck River study area and the Maury, Marshall, Bedford, and Coffee County water-service areas. 


\section{HYDROGEOLOGIC SETTING}

The upper Duck River basin drains parts of the Highland Rim and Central Basin physiographic regions of Tennessee (Miller, 1974) (fig. 2). The climate of the area is moderate, with annual rainfall averaging 46 inches per year. The river flows from the dissected limestone highlands in northern Coffee County into Normandy Reservoir, completed by the Tennessee Valley Authority (TVA) in 1976. The reservoir, with a capacity of 117,000 acre-feet, at normal maximum headwater elevation of 875 feet, is used for flood control, water supply, water-quality enhancements, and recreation. Downstream from Normandy Dam (fig. l), the river flows into Bedford County and through the city of Shelbyville, where municipal water withdrawals averaged $3.90 \mathrm{Mgal} / \mathrm{d}$ during 1989 . There are no major urban areas in the path of the river as it traverses Marshall County, although it supplied $2.71 \mathrm{Mgal} / \mathrm{d}$ during 1989 to Lewisburg and other smaller communities. The river then flows into Maury County and through the abandoned Columbia Dam (construction began in 1973 and was discontinued in 1983) (Jack L. Davis, Manager, Navigation and System Modification, Tennessee Valley Authority, oral commun., 1992) into the city of Columbia. Withdrawals in Columbia for municipal supplies averaged $8.48 \mathrm{Mgal} / \mathrm{d}$ during 1989 . Total drainage area of the basin at the western Maury County boundary is about 1,700 square miles.

Minimum flows of the upper Duck River in Bedford, Marshall, and Maury Counties increased significantly since the construction of Normandy Reservoir. The 3-day 20-year (3Q20) minimum flow represents the lowest mean daily flow on a consecutive 3 -day period with a recurrence interval of 20 years. Estimated values of 3 Q20 at Shelbyville and Columbia before (Bingham, 1985) and after (U.S. Geological Survey files, Nashville) completion of the damsite are as follows:

\begin{tabular}{|c|c|c|c|c|c|c|}
\hline \multirow[t]{2}{*}{ Station } & \multicolumn{2}{|c|}{$\begin{array}{c}\text { Before } \\
1976 \\
\end{array}$} & \multirow{2}{*}{$\begin{array}{l}\text { Period } \\
\text { of } \\
\text { record }\end{array}$} & \multicolumn{2}{|c|}{$\begin{array}{l}\text { After } \\
1976 \\
\end{array}$} & \multirow{2}{*}{$\begin{array}{l}\text { Period } \\
\text { of } \\
\text { record }\end{array}$} \\
\hline & $\mathrm{ft}^{3 / s}$ & $\mathrm{Mgal} / \mathrm{d}$ & & $\mathrm{ft}^{3} / \mathrm{s}$ & $\mathrm{Mgal} / \mathrm{d}$ & \\
\hline Shelbyville & 53.8 & 34.8 & 1949-76 & 71.3 & 46.1 & 1978-91 \\
\hline Columbia & 15.1 & 9.8 & 1905-08 & 95.4 & 61.7 & $1978-91$ \\
\hline
\end{tabular}

The different geologic and hydrographic conditions of the Highland Rim and Central Basin regions play an important role in the availability of ground-water resources in the area. The Highland Rim is underlain by chert and clay-rich limestone of the Warsaw Limestone and the Fort Payne Formation of Mississippian age (Miller, 1974). Although the occurrence of large quantities of ground water is variable and requires careful site selection, as much as 860 gallons per minute (gal $/ \mathrm{min}$ ) per well may be produced in a few places from the Fort Payne Formation (Burchett, 1977). Residuum in northeastern Bedford County, ranging in thickness from 10 to 80 feet, stores large quantities of ground water that discharges to tributaries in the basin. This discharge helps to maintain base flow in the Duck River as the river flows out of the Highland Rim region. In contrast, the Central Basin is underlain by the Murfreesboro, Ridley, Lebanon, Carters, and BigbyCannon Limestones of Ordovician age (Miller, 1974). The occurrence of ground water in these limestone rocks is extremely variable. The highest yields to wells occur at depths shallower than 150 feet in sheet-like dissolution openings, usually extending laterally a few thousand feet in any direction (Brahana and Hollyday, 1988). Yields to wells as high as $70 \mathrm{gal} / \mathrm{min}$ can occur within the Ridley Limestone (U.S. Geological Survey files, 1992). Residuum is usually less than 15 feet thick, stores little water, and as a consequence the natural base flow of the Duck River and its tributaries decreases downstream of Shelbyville (Burchett, 1977).

Ground-water use in the study area is for municipal and for domestic supply. The yields of several industrial wells that tap the Fort Payne Formation of the Highland Rim section in Coffee County are generally less than $100 \mathrm{gal} / \mathrm{min}$.

\section{WATER AVAILABILITY}

Surface- and ground-water availability in the upper Duck River basin varies seasonally, annually, and geographically. The Duck River is the main source of municipally used surface water in the basin. Springs and wells of varying yields supplement the municipal water supply from the Duck River and provide water to domestic systems. 


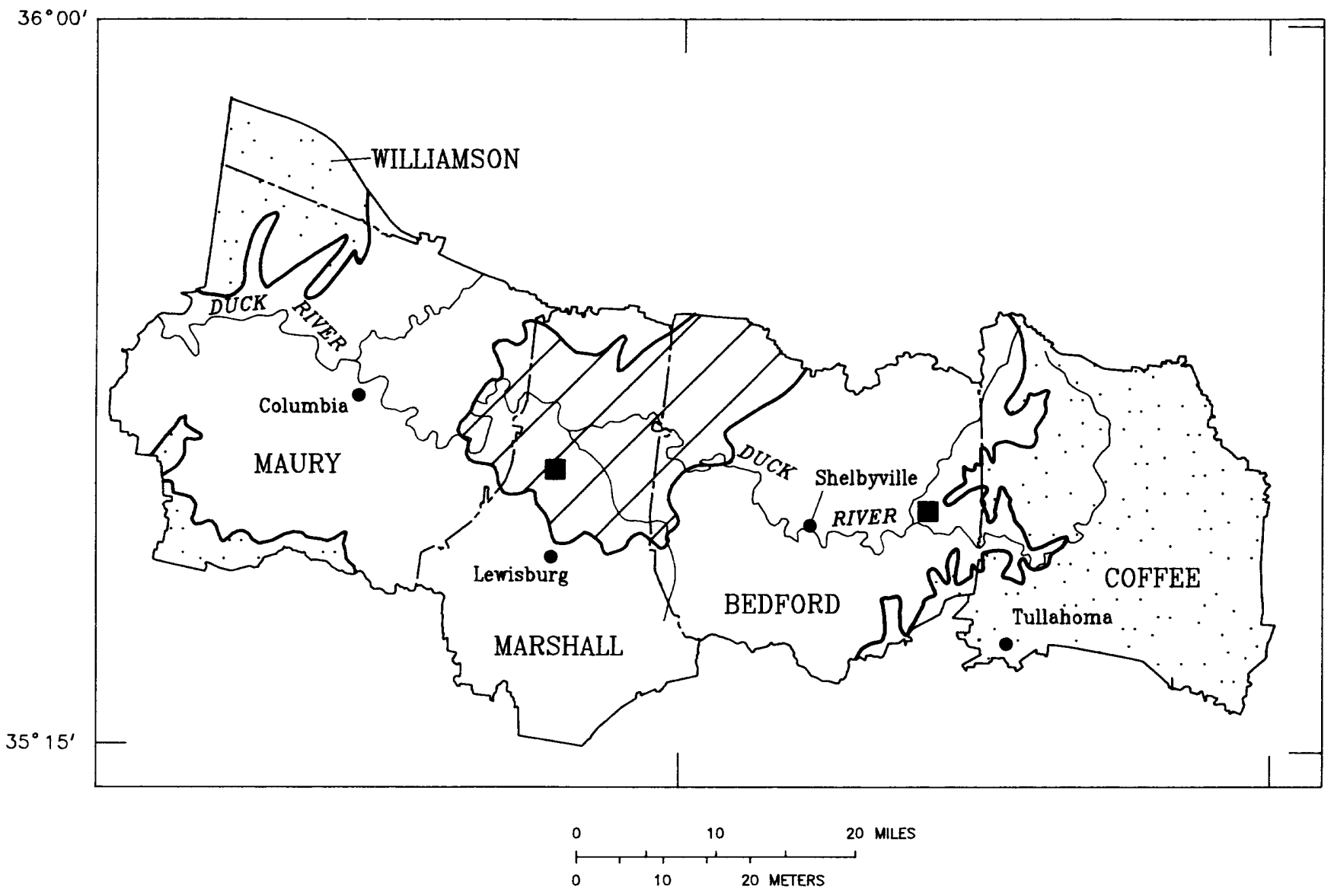

EXPLANATION

TENNESSEE

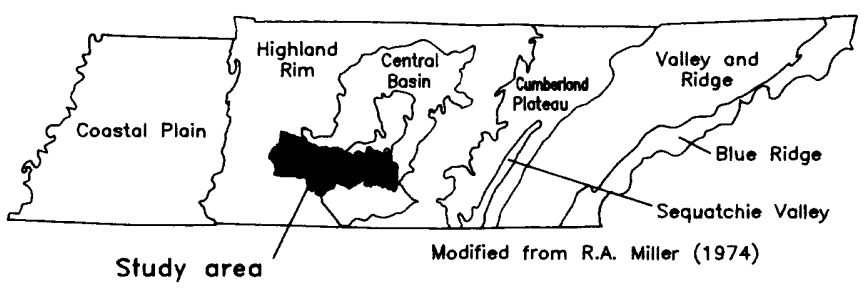

$\therefore$ FORT PAYNE AQUIFER

$\square \quad$ BIGBY-CANNON AQUIFER

$\square$ RIDLEY AQUIFER

- SEEPAGE INVESTIGATION

AQUIFER BOUNDARY

Figure 2. Physiographic regions, major aquifers, and seepage-investigation locations in the upper Duck River study area. 


\section{Surface Water}

Normandy Dam, at river mile 248.6, has regulated the flow of the Duck River since January 1976. Flow releases are controlled to meet water supply and waterquality requirements downstream from the damsite. Releases from the reservoir have increased since 1981 to meet growing municipal demands and to maintain water quality at Shelbyville (river mile 221.4). Initially, a minimum winter release of $60 \mathrm{ft}^{3} / \mathrm{s}$ (38.8 Mgal/d) was sustained. In 1987 , the minimum winter flow was increased to $80 \mathrm{ft}^{3} / \mathrm{s}(51.7 \mathrm{Mgal} / \mathrm{d})$, and in January 1992, to $120 \mathrm{ft}^{3} / \mathrm{s}$ (77.6 Mgal/d). Regulated summer flows at Shelbyville are higher, requiring a minimum flow of $155 \mathrm{ft}^{3} / \mathrm{s}(100.2 \mathrm{Mgal} / \mathrm{d})$ to ensure adequate water quality throughout the reach.

Low flows in the reach of the upper Duck River from Normandy Dam to the city of Columbia are used by Upper Duck River Development Agency and the Tennessee Valley Authority as an indicator of water availability. Low-flow statistics were obtained from analyzing 10 years of data (1979 to 1988) from USGS continuous-record gaging stations near Shelbyville (station 03598000) and downstream at Columbia (station 03599500). Analyses of the low-flow data show that:

- Minimum daily flow near Shelbyville is $72.0 \mathrm{ft}^{3} / \mathrm{s}$ (46.5 Mgal/d); the minimum 3-day flow is $77.0 \mathrm{ft}^{3} / \mathrm{s}$ (49.8 Mgal/d), recorded during October 1982.

- Minimum daily flow at Columbia is $86.0 \mathrm{ft}^{3} / \mathrm{s}$ (55.6 Mgal/d); the minimum 3-day flow is $89.0 \mathrm{ft}^{3} / \mathrm{s}$ (57.5 Mgal/d), recorded during October 1982.

- During the record drought of 1988 , minimum daily flow near Shelbyville was $87.0 \mathrm{ft}^{3} / \mathrm{s}(56.2 \mathrm{Mgal} / \mathrm{d})$; at Columbia, $128 \mathrm{ft}^{3} / \mathrm{s}(82.7 \mathrm{Mgal} / \mathrm{d})$.

\section{Ground Water}

The elements of the study related to ground water were limited to:

- An inventory of well data to determine range of yields to wells within each county in the study area; and

- A seepage investigation in two subbasins to identify areas for potential ground-water development.

The scope of the project did not include an in-depth assessment of the ground-water resources in the study area. The information collected is inadequate to provide a practical assessment of the potential for development of additional ground-water supplies throughout the basin. The complex nature of the geology and ground-water flow in the limestone rock fractures underlying the basin will require additional investigation to properly assess the ground-water resources. Such an investigation would involve extensive data collection and test drilling.

A summary of yields to wells within the study area was compiled from files maintained by the USGS and the Tennessee Division of Water Supply (TDWS), Tennessee Department of Environment and Conservation (TDEC). The files contained records of 5,938 municipal, industrial, and domestic wells with a diameter of 6 inches or greater. Statistical analysis of yields from the wells in the inventory was performed. The values of the median and quartiles (25th and 75th percentile) are graphically displayed as box plots (fig. 3). Extreme values (those greater than $100 \mathrm{gal} / \mathrm{min}$.) are not displayed so that the quartile ranges may be more clearly represented. In Bedford County, 9 wells had yields greater than $100 \mathrm{gal} / \mathrm{min}$; Coffee County, 117 wells; Marshall County, 6 wells; and Maury County, 13 wells. The analyses showed that:

- Median yields to wells ranged from $5 \mathrm{gal} / \mathrm{min}$ in Maury County to $20 \mathrm{gal} / \mathrm{min}$ in Coffee County.

- Maximum yields were recorded from wells in Coffee County, with 25 percent of the wells 

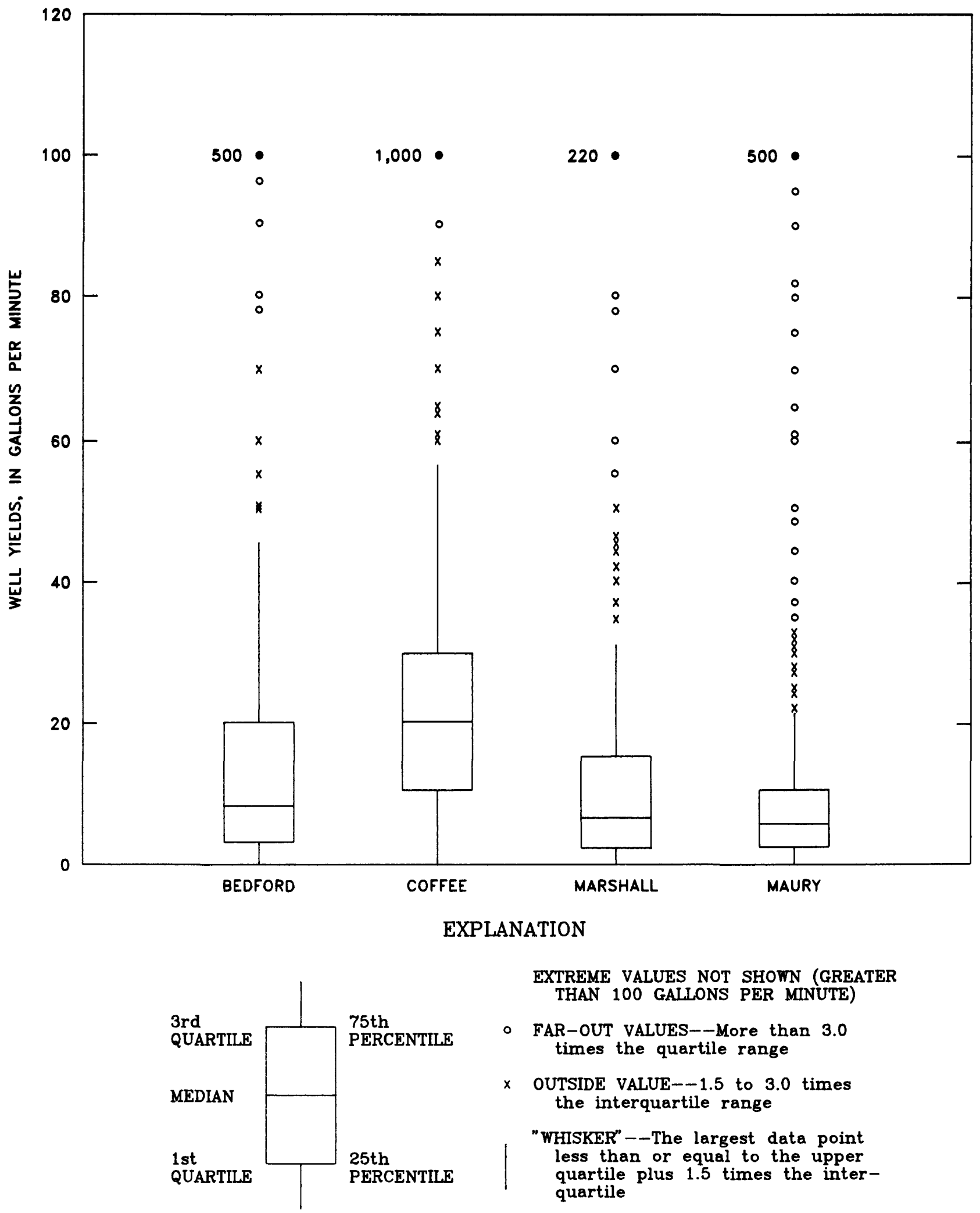

EXTREME VALUES NOT SHOWN (GREATER THAN 100 GALLONS PER MINUTE)

- FAR-OUT VALUES--More than 3.0 times the quartile range

$x$ OUTSIDE VALUE-- 1.5 to 3.0 times the interquartile range

"WHISKER" - -The largest data point less than or equal to the upper quartile plus 1.5 times the interquartile

500 - MAXIMUM YIELD TO WELL FOR COUNTY, IN GALLONS PER MINUTE

Figure 3. Distribution of yields to wells 100 gallons per minute and less by county in the upper Duck River basin. 
exceeding $30 \mathrm{gal} / \mathrm{min}$, and a maximum individual yield of $1,000 \mathrm{gal} / \mathrm{min}$.

- Lowest yields were recorded in wells from Maury County, with 25 percent of the wells with yields of $12 \mathrm{gal} / \mathrm{min}$ or more. However, wells with yields as high as $500 \mathrm{gal} / \mathrm{min}$ have been drilled in the county.

The statistical analyses suggest that there is less likelihood that a well constructed in Maury County will have a yield as large as $100 \mathrm{gal} / \mathrm{min}$ as would a well constructed in Coffee County. However, the potential for ground-water development of a specific site in either county must be evaluated on factors pertinent to that site, rather than on statistical data of the entire county.

Seepage investigations can be used to screen potentially more productive areas from less productive areas within a ground-water basin prior to drilling (Burchett, 1977). The method uses discharge measurements made at selected points along a stream and its tributaries. The measurements must be made during a period of no surface runoff. Under this condition, streamflow is composed entirely of aquifer discharge. Using a large-scale map (preferably a $71 / 2$-minute topographic quadrangle map) to locate each measurement site, the drainage area for the site is measured and both the change in drainage area $(\Delta A)$ and the change in discharge $(\Delta Q)$ from the next site upstream are calculated. Relatively large values of the ratio of change in discharge to change in drainage area $\left(\Delta Q / \Delta A\right.$, where $\Delta A$ is at least $\left.0.01 \mathrm{mi}^{2}\right)$ reflect significant gains from the aquifer (or losses to the aquifer when the ratio results in a negative value), and indicate areas where water flows through the aquifer with a relative degree of ease. Rock or sediments in these areas has greater permeability than that in areas characterized by low $\Delta Q / \Delta A$ values, and potentially will provide greater yields of water to wells.

For this study, two seepage investigations were conducted: one at Hurricane Creek basin (Bedford County) and another at the East Fork of Big Rock Creek basin (Marshall County) (fig. 2). Analyses of the data from the studies (table 1) indicate several sites with comparatively high ratios of $\Delta Q / \Delta A$, suggesting the potential for ground-water development in these subbasins. Discharge and area data are presented in Flohr and others (1991). A previous seepage investigation in several subbasins within Maury and Williamson Counties also showed several sites with potential for ground-water development (Lowery and others, 1987). Confirmation of the actual ground-water resources in these areas will require detailed investigations and test drilling.

Table 1. Seepage investigations in the upper Duck River basin

\begin{tabular}{|c|c|c|c|c|c|}
\hline $\begin{array}{c}\text { Site } \\
\text { number }\end{array}$ & $\begin{array}{l}\text { Site } \\
\text { name }\end{array}$ & County & Aquifer & $\begin{array}{c}\text { Date } \\
\text { of } \\
\text { measure- } \\
\text { ment }\end{array}$ & $\begin{array}{c}\text { Number } \\
\text { of } \\
\text { measure- } \\
\text { ments }\end{array}$ \\
\hline 1 & $\begin{array}{c}\text { Spring } \\
\text { Hill. }\end{array}$ & $\begin{array}{l}\text { Maury and } \\
\text { Williamson. }\end{array}$ & $\begin{array}{l}\text { Bigby- } \\
\text { Cannon. }\end{array}$ & 4-21-87 & 45 \\
\hline 2 & $\begin{array}{c}\text { Hurricane } \\
\text { Creek. }\end{array}$ & Bedford & $\begin{array}{l}\text { Bigby- } \\
\text { Cannon. }\end{array}$ & $4-04-90$ & 33 \\
\hline 3 & $\begin{array}{c}\text { East Fork } \\
\text { of Big } \\
\text { Rock Cre }\end{array}$ & Marshall & Ridley & $4-05-90$ & 24 \\
\hline
\end{tabular}

\section{WATER USE}

The upper Duck River basin is divided into four municipal water-service areas (WSA's)--Bedford, Coffee, Marshall, and Maury--whose boundaries closely coincide with their respective county boundaries (fig. 1). Municipal water use in the basin increased 16 percent from 1980 to 1990 (Alexander and others, 1984; Tennessee Division of Water Supply files, 1990; U.S. Geological Survey files, 1985, 1988, and 1990) (table 2). Correspondingly, the number of customer connections increased about 13 percent. Most of the increase occurred in recent years. The Maury WSA had an increase in water use of 11 percent from 1988 through 1990, the largest in the study area. Overall water use in the basin in the same period increased only 7.4 percent. These increases in water use are principally due to growth in the residential and industrial sectors. 
Table 2. Water-service area withdrawals and number of customer connections

[Source: U.S. Geological Survey unpublished data, 1990]

\begin{tabular}{|c|c|c|c|c|c|c|c|}
\hline \multirow{2}{*}{$\begin{array}{l}\text { Water-service } \\
\text { area }\end{array}$} & \multicolumn{5}{|c|}{$\begin{array}{l}\text { Withdrawals, in } \\
\text { million gallons per day }\end{array}$} & \multicolumn{2}{|c|}{$\begin{array}{l}\text { Number } \\
\text { of } \\
\text { connections }\end{array}$} \\
\hline & 1980 & 1985 & 1988 & 1989 & 1990 & 1980 & 1990 \\
\hline Bedford & 3.81 & 3.62 & 3.99 & 4.36 & 4.20 & 8,666 & 10,056 \\
\hline Coffee & 3.50 & 3.62 & 3.94 & 3.83 & 3.95 & 10,780 & 12,121 \\
\hline Marshall & 2.27 & 2.51 & 2.61 & 2.82 & 2.85 & 5,338 & 6,333 \\
\hline Maury & 8.43 & 8.75 & 8.94 & 9.41 & 9.93 & 16,972 & 18,612 \\
\hline Basin totals & 18.01 & 18.50 & 19.48 & 20.42 & 20.93 & 41,756 & 47,122 \\
\hline
\end{tabular}

Weather affects the water-use patterns in the basin. During the summer season (May, June, July, and August) when temperatures are higher, water use increases because of outdoor use. If rainfall is below normal for the season, water use increases even more. Precipitation data from a weather station at Columbia and water-withdrawal records from the Columbia Water Department (Maury WSA) for a drought year (1988) were compared to data for a year with sufficient summer precipitation (1989) (fig. 4). During 1988, the total departure from normal rainfall during the summer season (May, June, July, and August) was -6.6 inches (U.S. Department of Commerce, 1989). Water use during this period of 1988 averaged $9.02 \mathrm{Mgal} / \mathrm{d}$, or 13 percent above the 1988 annual average water use of $7.98 \mathrm{Mgal} / \mathrm{d}$ (table 3). In comparison, rainfall during the summer season of 1989 was 5.90 inches above normal (U.S. Department of Commerce, 1990). During this period, water use averaged $8.78 \mathrm{Mgal} / \mathrm{d}$, or 3.5 percent above the 1989 annual average water use of $8.48 \mathrm{Mgal} / \mathrm{d}$ (U.S. Geological Survey files, 1989) (fig. 4).

The seasonal increase can be expressed also as a ratio of water use in summer to water use in winter. For the Columbia Water Department (Maury WSA), the ratio in 1988 was $1.21(9.02 \mathrm{Mgal} / \mathrm{d}$ to
$7.47 \mathrm{Mgal} / \mathrm{d}$ ) (table 4). That is, for every 121 gallons per day used during the summer season, a household used 100 gallons per day during the winter season. Summer sprinkling (outdoor usage) accounts for the difference (Howe and Linaweaver, 1967).

Water use for the public-supply systems and municipally supplied industries in the study area for 1989 was estimated from an inventory of use. The inventory was conducted in 1990 in cooperation with TDWS. Twenty-four public-supply systems provided data detailing the source of supply; daily averageannual amount of water withdrawn or purchased (table 5); maximum daily withdrawal; population served; number of connections; distribution amounts to residential, commercial, and industrial users; conveyance losses; and free service. The municipally supplied industries provided data detailing their source(s) of supply, daily water usage, normal operation schedule, Standard Industrial Classification (SIC) categories, and number of employees. The results of the inventory indicated that:

- Municipal withdrawals during 1989 totaled 20.4 Mgal/d (table 2).

- The Duck River surface water accounted for 93 percent of the withdrawals $(18.9 \mathrm{Mgal} / \mathrm{d})$; the 

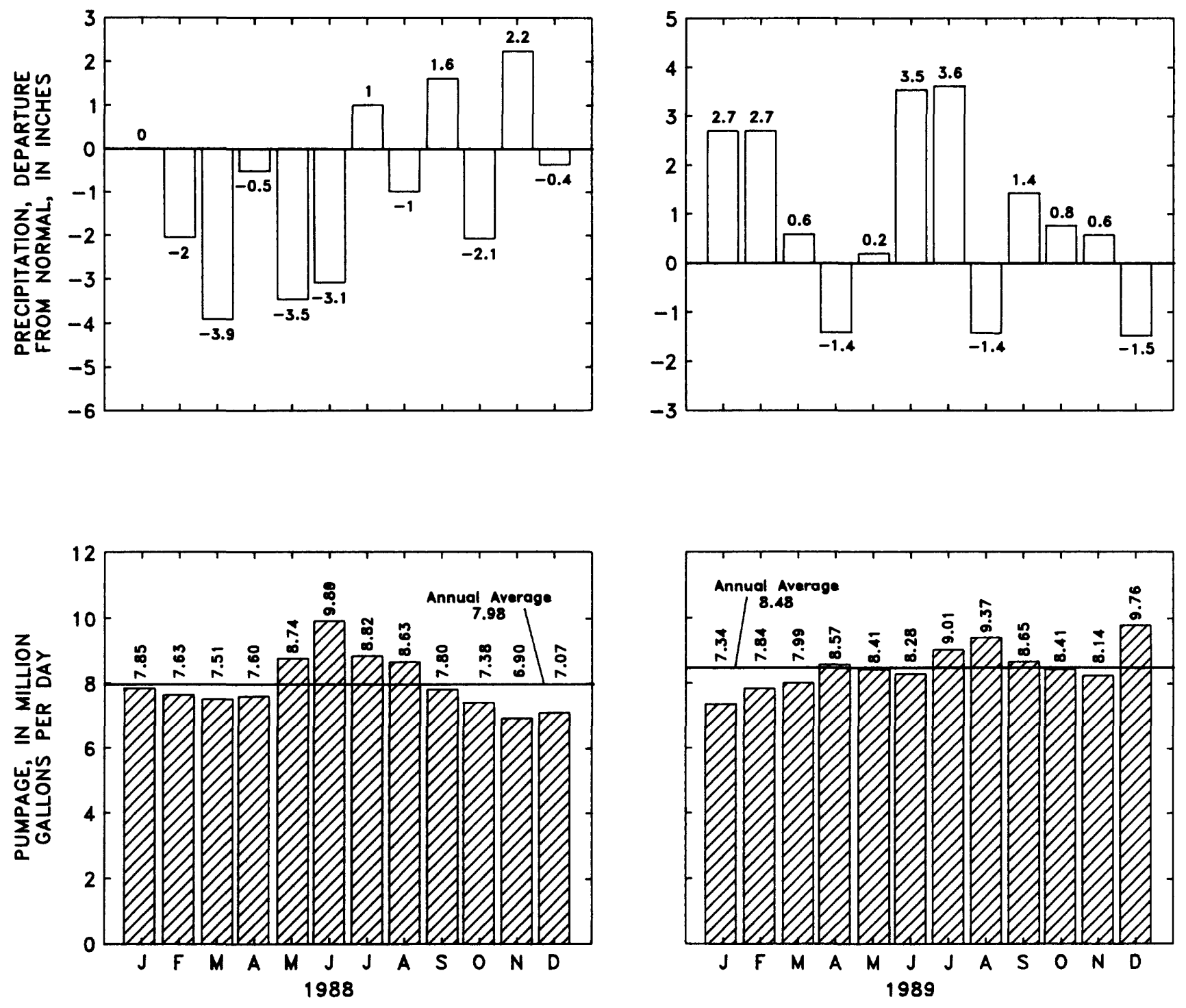

Figure 4. Monthly water withdrawals by Columbia Water Department and monthly departure from normal precipitation statistics for Columbia, Tennessee, for 1988 and 1989. 
Table 3. Average daily water withdrawals by month for major public-supply systems during 1988

[Summer reason usage (outdoor and indoor); and winter season usage (indoor)]

\begin{tabular}{|c|c|c|c|c|}
\hline \multirow[b]{2}{*}{ Month } & \multicolumn{4}{|c|}{ Withdrowals, in million gallons per day, for indicated public water-supply syatem } \\
\hline & $\begin{array}{l}\text { Columbia } \\
\text { Water } \\
\text { Dopartmont }\end{array}$ & $\begin{array}{l}\text { Lewisburg } \\
\text { Water } \\
\text { Syetem }\end{array}$ & $\begin{array}{c}\text { Shelbrville } \\
\text { Wotor } \\
\text { Systom }\end{array}$ & $\begin{array}{l}\text { Duck River } \\
\text { Utillity } \\
\text { Commiesior }\end{array}$ \\
\hline \multicolumn{5}{|c|}{ Winter season } \\
\hline January & 7.85 & 2.39 & 2.96 & 3.92 \\
\hline February & 7.63 & 2.28 & 2.72 & 3.84 \\
\hline March & 7.51 & 2.31 & 2.50 & 3.80 \\
\hline April & 7.60 & 2.43 & 2.61 & 3.90 \\
\hline September & 7.80 & 2.51 & 2.88 & 3.87 \\
\hline October & 7.38 & 2.49 & 2.66 & 3.59 \\
\hline November & 6.90 & 2.48 & 2.73 & 3.30 \\
\hline December & 7.07 & 2.52 & 2.84 & 3.48 \\
\hline Average & 7.47 & 2.43 & 2.74 & 3.71 \\
\hline \multicolumn{5}{|c|}{ Summer season } \\
\hline May & 8.74 & 2.66 & 2.80 & 4.27 \\
\hline June & 9.89 & 2.89 & 3.21 & 4.86 \\
\hline July & 8.82 & 2.48 & 2.89 & 4.17 \\
\hline August & 8.63 & 2.59 & 3.03 & 4.34 \\
\hline Average & 9.02 & 2.66 & 2.98 & 4.41 \\
\hline $\begin{array}{l}\text { Annual } \\
\text { average }\end{array}$ & 7.98 & 2.50 & 2.82 & 3.94 \\
\hline
\end{tabular}

Table 4. Seasonal and maximum daily water-use ratios for major public-supply systems for 1988

[Summer, May through August; Winter, September through April; WD, Water Department; WS, Water System; UC, Utility Commission]

\begin{tabular}{|c|c|c|c|c|c|c|c|}
\hline \multirow{2}{*}{ System } & \multicolumn{4}{|c|}{$\begin{array}{l}\text { Daily average withdrawal, } \\
\text { in million gallons per day }\end{array}$} & \multicolumn{3}{|c|}{ Ratio } \\
\hline & Summer & Winter & Annual & Maximum & $\begin{array}{l}\text { Summerl } \\
\text { Winter }\end{array}$ & $\begin{array}{l}\text { Summorl } \\
\text { annual }\end{array}$ & $\underset{\text { Maximum }}{\text { annual }}$ \\
\hline Columbia WD & 9.02 & 7.47 & 7.98 & 12.31 & 1.21 & 1.13 & 1.54 \\
\hline Lewisburg WS & 2.66 & 2.43 & 2.50 & 3.81 & 1.09 & 1.06 & 1.52 \\
\hline Shelbyville WS & 2.98 & 2.74 & 2.82 & 4.14 & 1.09 & 1.06 & 1.47 \\
\hline Duck River UC & 4.41 & 3.71 & 3.94 & 5.74 & 1.19 & 1.12 & 1.46 \\
\hline
\end{tabular}


Table 5. Public-supply facilities, source(s) of supply, and water use in the upper Duck River basin, Tennessee

[Mgal/d, million gallons per day; WSA, water-service area; _, no transaction; WS, Water System; Co., county; UD, Utility District; e, estimated; UC, Utility Commission; MCBPU, Marshall County Board of Public Utilities; WD, Water Department; and, MHP, mobile home park]

\begin{tabular}{lcc}
\hline Facility & $\begin{array}{c}\text { Source } \\
\text { of supply } \\
\text { (river mile) }\end{array}$ & $\begin{array}{c}\text { Withdrawals, } \\
\text { in Mgal/d }\end{array}$ \\
\hline
\end{tabular}

\section{Bedford WSA}

Shelbyville Water System

Bedford County UD \#1

Bedford County UD $\# 2$

Bell Buckle Water System

Wartrace Water System

Flat Creek Cooperative

Manchester Water Department

Tullahoma Board of Utilities

Duck River Utility Commission

Hillsville Utility District

Shady Grove MHP

Stacy Anne's MHP

Chapel Hill Water System

Marshall County Board of Public Utilities

Cornersville Water Department

Petersburg Water System

Lewisburg Water System

Henry Horton State Park

Columbia Water Department

Mount Pleasant Water System \#1

Spring Hill Water Department

Maury County Water System

Mount Pleasant Water System \#2

Hillsboro and Thompson Station Utility District
Duck River (227.0)

Duck River (202.4)

Shelbyville WS

Bedford Co. UD \#1

Wartrace WS

Wartrace WS

Cascade Spring

Shelbyville WS

\section{Coffee WSA}

Duck River UC

Duck River UC

Duck River (255.0)

Manchester WD

well

well

\section{Marshall WSA}

\section{MCBPU \#1}

Town Well

Lewisburg WS

Lewisburg WS

Fayetteville WS

Duck River (181.0)

MCBPU \#1

Chapel Hill WS

\section{Maury WSA}

Duck River (133.7)

$$
\text { Spring }
$$

Columbia WD

Columbia WD

Columbia WD

Spring Hill WD

$\begin{array}{ll}3.22 & - \\ .683 & - \\ - & 0.080 \\ -.452 & .140 \\ - & -.140\end{array}$

\begin{tabular}{lr}
- & 1.59 \\
\hline 3.83 & 2.10 \\
$-.007 e$ & -.278 \\
.007 & -
\end{tabular}

$\begin{array}{lr}\overline{0} .114 & 0.000 \\ - & -.300 \\ - & .090 \\ -2.71 & .050 \\ - & -.021 \\ - & -\end{array}$

$\begin{array}{cr}8.48 & - \\ .930 & - \\ - & .560 \\ - & .140 \\ - & .130 \\ - & .360\end{array}$


remaining 7 percent or $1.5 \mathrm{Mgal} / \mathrm{d}$ was withdrawn from springs and wells (table 5).

- Normandy Reservoir provided 20 percent of the surface water, or $3.83 \mathrm{Mgal} / \mathrm{d}$ (Duck River Utility Commission). The remaining 80 percent is withdrawn downstream of Normandy Reservoir at four public-supply intakes on the Duck River (Shelbyville, Bedford County Utility District, Lewisburg, and Columbia).

- During 1989, residential-sector water use accounted for 41 percent $(8.36 \mathrm{Mgal} / \mathrm{d})$ of total municipal water use; commercial, 10 percent $(2.02 \mathrm{Mgal} / \mathrm{d})$; industrial, 28 percent (5.64 Mgal/d); and, public/unaccounted water, 22 percent $(4.4 \mathrm{Mgal} / \mathrm{d})$ (table 6).

Table 6. Public-supply deliveries of water to various wateruse sectors during 1989

[Mgal/d, million gallons per day]

\begin{tabular}{lcccc}
\hline & \multicolumn{4}{c}{ Sector } \\
\cline { 2 - 5 } $\begin{array}{l}\text { Water-service } \\
\text { area }\end{array}$ & Residential & Commercial & Industrial & $\begin{array}{c}\text { Public/ } \\
\text { unaccounted } \\
\text { (Mgal/d) }\end{array}$ \\
& (Mgal/d) & (Mgal/d) & (Mgal/d) & (Mgl \\
\hline Bedford & 1.62 & 0.192 & 0.957 & 1.59 \\
Coffee & 1.90 & .503 & .499 & .931 \\
$\begin{array}{l}\text { Marshall } \\
\text { Maury }\end{array}$ & 1.36 & .215 & .616 & .629 \\
Basin totals & 3.48 & 1.11 & 3.57 & 1.25 \\
& 8.36 & 2.02 & 5.64 & 4.40 \\
\hline
\end{tabular}

\section{WATER-DEMAND SIMULATION}

Future municipal water demands within the upper Duck River basin were estimated using the Institute for Water Resources-Municipal and Industrial Needs System. Econometric demand and requirement (usually of the unit-use type) models calculated water demand as a function of socioeconomic parameters. Each of these parameters was projected for the future years for which water demand was estimated.
The IWR-MAIN System is used primarily to test assumptions and the effects that various assumptions or changes would have on water use in the basin rather than as a predictive tool to generate absolute values showing future water use. This use of the system and the basic assumptions about growth, land use, population, and technology determine the results. If the assumptions are changed (for example, population decreases in the area), the water-demand results will change. The results depend on the validity of the assumptions.

\section{Model Description}

The IWR-MAIN System is a water-demand forecasting system that contains a range of water-use models, socioeconomic-parameter generating procedures, and data-management techniques (U.S. Army Corps of Engineers, 1988). Nonmunicipal or rural water demand is not simulated by the IWR-MAIN System. The IWR-MAIN System architecture allows for spatial, sector, and seasonal disaggregation of a study area (fig. 5). The unit for spatial disaggregation is the WSA. This unit may correspond to a city-wide or county-wide public-supply facility or consist of all public-supply facilities within a county or basin. The system divides municipal water users within each WSA into four major sectors: residential, commercial, industrial, and public/unaccounted. Each sector is further disaggregated into a number of categories for simulation purposes (fig. 5). The seasonal dimensions of the system consider any one of the elements of annual average, winter or summer season, or maximum daily use for each sector and category.

The relation between the calibration and the simulation processes of the IWR-MAIN System is displayed graphically in figure 6 . The schematic illustrates how the data modules (top) relate to the computational modules (middle) and to the results (bottom). The base-year data are used to produce future-year data by means of internal models that project growth for the various socioeconomic parameters. The growth in economic parameters (future data) also may be produced 
Number of housing units by type, density and market-value range; average lot size; persons per household; and Composite Construction Cost Index

Number of employees by 3-digit Standard Industrial Classification (SIC) groups

Water and wastewater prices and rate structures; marginal price; bill difference

Climatic/weather conditions (moisture deficit)

Residential population, income and employment

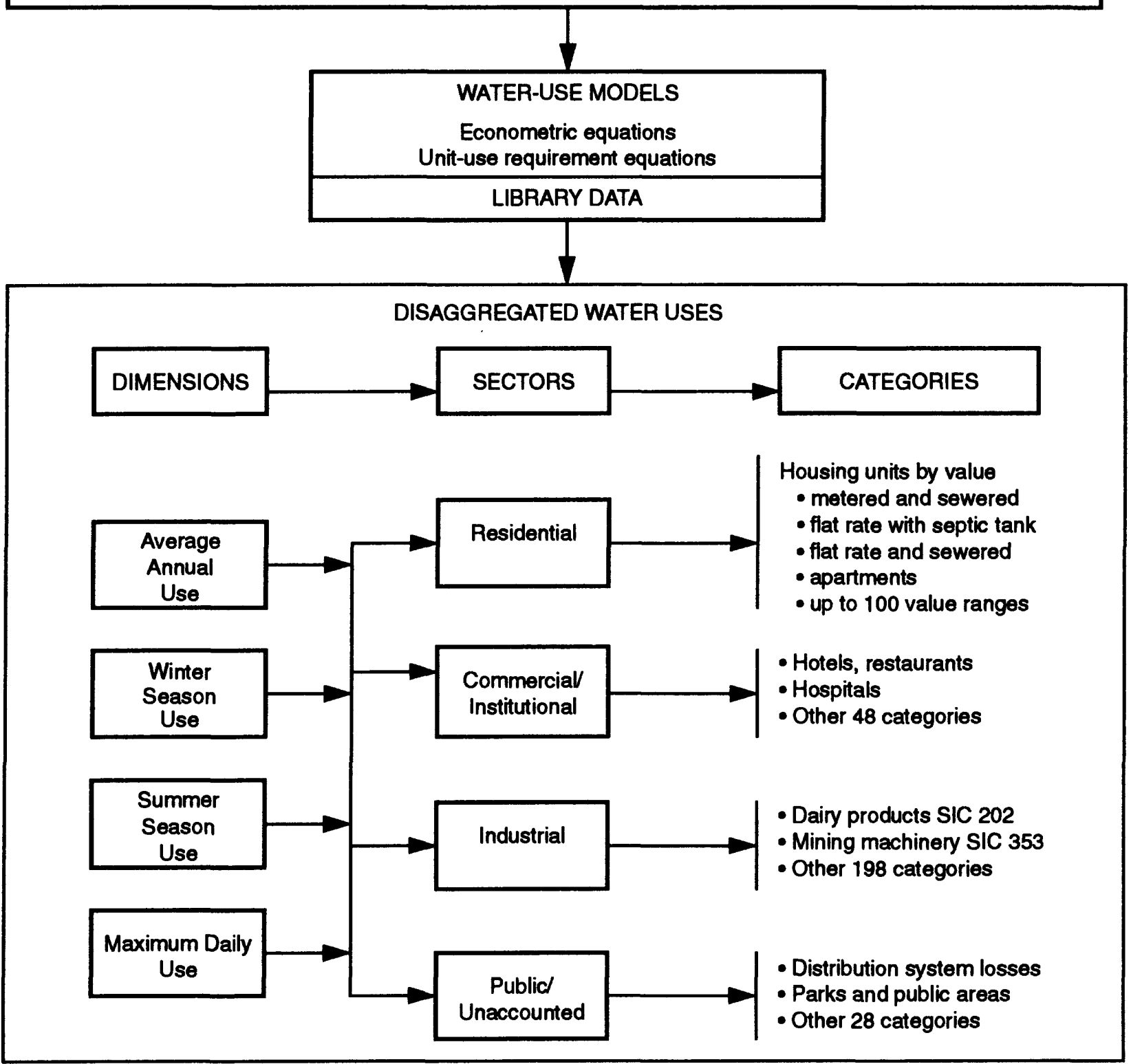

Modified from U.S. Army Corps of Engineers (1988)

Figure 5. Schematic describing the Institute for Water Resources-Municipal and Industrial Needs System architecture. 


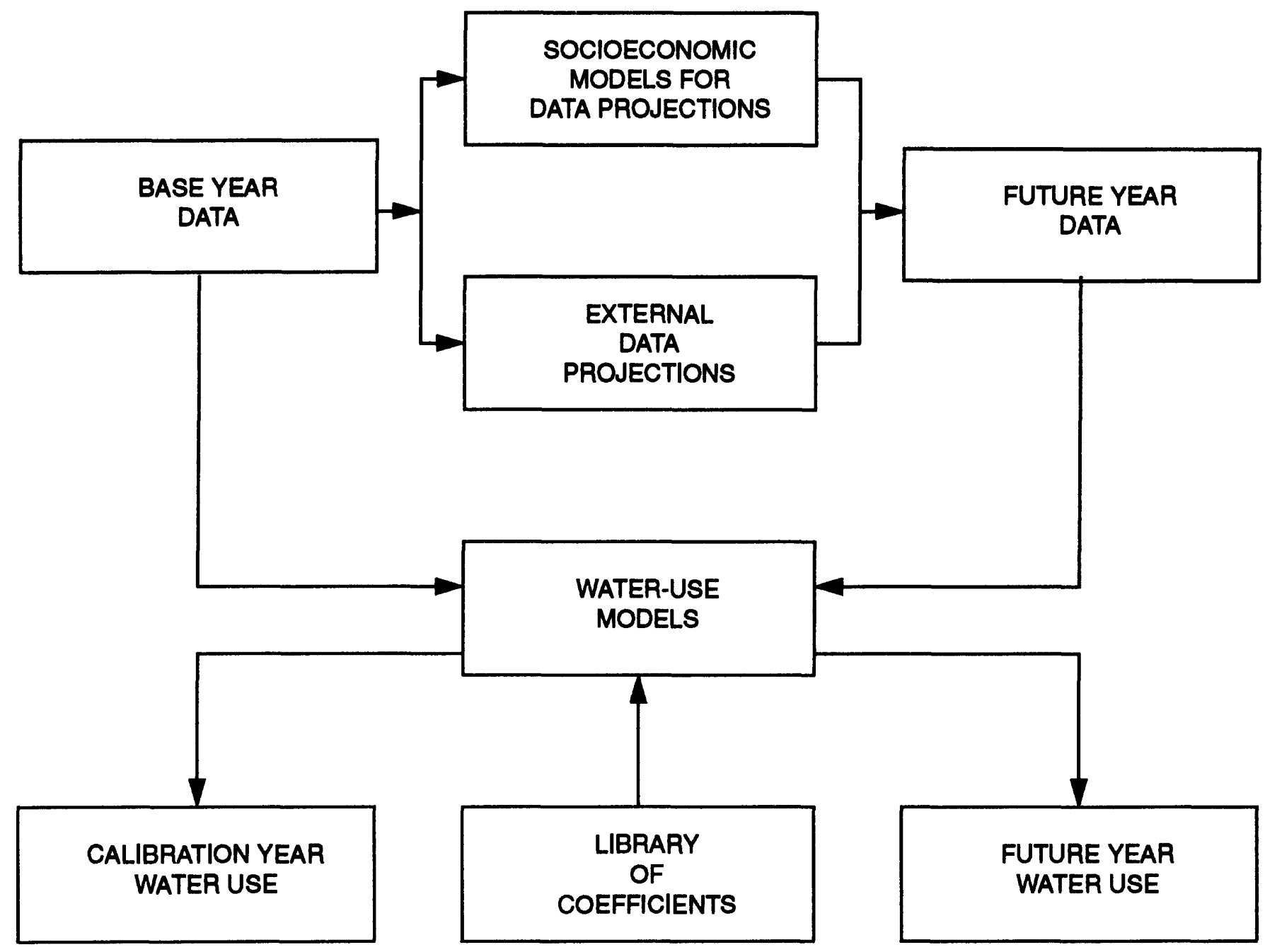

Modified from U.S. Army Corps of Engineers (1988)

Figure 6. Schematic relating the calibration and simulation processes of the Institute for Water Resources-Municipal and Industrial Needs System to data, computational subroutine, library, and result modules.

externally by the user and added to the model. Base (or calibration) year data are incorporated into the water-use models to simulate base (or calibration) year water use. If the base and calibration year are different years, selected future-year data also are incorporated into the model. The water-use models are calibrated by adjusting the library values--model constants, parameter coefficients, climatic values--to reflect local socioeconomic and climatic conditions. Base-year and future-year data are manipulated by the water-use models to calculate water demand for future years.

The 5.1 version of the IWR-MAIN System was used in this study (U.S. Army Corps of Engineers, 1988). The user's manual and system description 
provides additional details for much of the discussion presented in this section of the report.

\section{Demand Models}

The econometric water-demand models relate socioeconomic parameters to water use for the residential, industrial, and commercial sectors (table 7). For the purposes of this study, these models were applied only to the residential sector. In this study, the residential sector was disaggregated into two categories: (1) metered and sewered, and (2) flat rate with septic tank (fig. 5). The number of housing units in each category is the significant variable driving the residential models. Housing value and price of water are the principal economic variables.

Table 7. Socioeconomic parameters input to the Institute for Water Resources-Municipal and Industrial Needs System

[SIC, Standard Industrial Classification]

\begin{tabular}{|c|c|}
\hline $\begin{array}{c}\text { Required } \\
\text { base-year paremeters }\end{array}$ & Future-year parameters \\
\hline $\begin{array}{l}\text { Number of residences by } \\
\text { type and value range } \\
\text { Commercial and industrial } \\
\text { employment by SIC } \\
\text { Number of persons per } \\
\text { household } \\
\text { Median household income } \\
\text { Resident population } \\
\text { Water and sewer rate structure } \\
\text { Composite construction cost index } \\
\text { Bill difference } \\
\text { Climatic conditions } \\
\text { Total population }\end{array}$ & $\begin{array}{l}\text { Number of housing units by } \\
\text { type and value range } \\
\text { Commercial and industrial } \\
\text { employment by SIC } \\
\text { Total employment } \\
\text { Median household income } \\
\text { Resident population' }\end{array}$ \\
\hline
\end{tabular}

${ }^{1}$ Required model input.

\section{Metered and Sewered Residential Model}

Water demand for the metered and sewered (MW) category is calculated for each housing value range for the winter and summer seasons by applying multiple- coefficient demand models containing elasticities for housing value and water use. Water use is then aggregated by the model to produce a weighted residential water use for the water-service area, including maximum daily and annual average use. Housing value acts as a proxy for income. Marginal price and bill difference (Appendix $A$ ) variables capture the effects of change in the water-rate structure on disposable income.

The MW winter-demand equation demonstrates a linear relation between quantity of water and various housing and pricing variables. As the following equation indicates, the projected quantity of water increases as the housing values increase; and water demand decreases as the marginal price of water and the effective annual bill difference increase.

$$
\left(\mathrm{Q}_{\mathrm{D}}\right)_{\mathrm{ms}}=\left(234+1.451 \mathrm{~V} / \mathrm{F}_{\mathrm{a}}-45.9 \mathrm{P}_{\mathrm{a}}-2.59 \mathrm{I}_{\mathrm{a}}\right) \mathrm{N}_{\mathrm{r}},
$$

where

$\mathrm{Q}$ is water usage, in gallons per day;

D is winter or indoor water use;

$\mathrm{ms}$ is metered and sewered;

234 is y-intercept, number of gallons per household per day;

$\mathrm{V}$ is average house value in a range of value per $\$ 1,000$;

$F_{a}$ is assessment factor;

$P_{a}$ is effective annual marginal price of water, in dollars per 1,000 gallons;

$I_{a}$ is effective annual marginal price of water, in dollars per billing period; and

$N_{r}$ is number of residences in value range $r$.

Summer usage includes indoor and outdoor usage. Outdoor usage is related to lawn or garden sprinkling, car washing, or other similar activity. Irrigable land and moisture deficit are variables which factor into the MW summer equation quantifying this additional usage as follows:

$$
\begin{aligned}
\left(\mathrm{Q}_{\mathrm{s}}\right)_{\mathrm{m}, \mathrm{e}}=(385 & +2.876 \mathrm{~V} / \mathrm{F}_{\mathrm{a}}-285.8 \mathrm{P}_{\mathrm{s}}-4.35 \mathrm{I}_{\mathrm{s}} \\
& +157.77 * \mathrm{~B} * \mathrm{MD}) \mathrm{N}_{\mathrm{r}}
\end{aligned}
$$


where

. is summer season;

is east of the 100th meridian;

385 is y-intercept, number of gallons per person per day;

$P_{\mathbf{a}}$ is effective summer marginal price of water, in dollars per 1,000 gallons;

$I_{\text {I }}$ is effective summer bill difference variable, in dollars per billing period;

$B$ is irrigable land per dwelling unit, in acres per unit;

MD is summer-season moisture deficit, in inches; and

$\mathrm{Q},{ }_{\mathrm{m}}, \mathrm{V}, \mathrm{F}_{\mathrm{a}}, \mathrm{B}$, and $\mathrm{N}_{\mathrm{r}}$ are as defined in equation (1).

Irrigable land is a function of housing density and is derived from the following equation:

$$
B=0.803 * \mathrm{Hd}^{-1.26}
$$

where

Hd is housing density, and

$B$ is as defined in equation (2).

Only the equation for the summer MW category includes weather conditions as a factor for influencing water demand. Precipitation and evapotranspiration values read from the IWR-MAIN Library of Climatic Variables produce values for the moisture deficit (MD) parameter. The latitude and longitude determine these precipitation and evapotranspiration values for each WSA (table 8). These climatic variables may be adjusted by the user to describe different climatic scenarios. Summer-season moisture deficit, MD, is calculated as follows:

$$
\mathrm{MD}=\mathrm{E}-0.6 \mathrm{R}
$$

where

E is summer-season potential evaporation, in inches; and

$R$ is summer-season precipitation, in inches.

Flat Rate with Septic Tank Residential Model

The flat rate with septic tank (FP) residential model estimates water use for the winter season as a function
Table 8. Climatological variables for the water-service areas

[Source: IWR-MANN Library of Climatic Variables; rain and evapotranspiration measurements for the summer season (June, July, and August) based on long-term average weather data as of 1967]

\begin{tabular}{llcc}
\hline $\begin{array}{c}\text { Water-service } \\
\text { ares }\end{array}$ & $\begin{array}{c}\text { Evapotranspiration } \\
\text { Total } \\
\text { (inchos) }\end{array}$ & $\begin{array}{c}\text { Maximum daily } \\
\text { (inches) }\end{array}$ & $\begin{array}{c}\text { Precipitation } \\
\text { (inches) }\end{array}$ \\
\hline Bedford & 17.25 & 0.29 & 11.00 \\
Coffee & 17.25 & .29 & 11.00 \\
Marshall & 18.50 & .29 & 10.50 \\
Maury & 18.50 & .29 & 10.50 \\
& & & \\
\hline
\end{tabular}

of persons per household and the number of housing units by value range. The equation constant, 30.2, represents the number of gallons per household per day. The FP category includes housing units that are occupied by customers who face a zero marginal price. This category is often used as a user-defined category to include, for example, housing units which are selfsupplied. The equation is as follows:

where

$$
\left(\mathrm{Q}_{\mathrm{D}}\right)_{\mathfrak{t}}=\left(30.2+39.5 \mathrm{D}_{\mathrm{p}}\right) \mathrm{N}_{\mathrm{r}}
$$

ft is flat rate with septic tank residential use,

$D_{p}$ is persons per household, and

$Q,{ }_{D}$, and $N_{r}$ are as defined in equation (1).

In the FP summer-usage equation, an exponential relation exists between housing value and water use. For each 1-percent increase in housing value, water use increases 0.783 percent. Also winter usage is a variable. The relation of water quantity to the variables is as follows:

$\left(Q_{\mathfrak{t}}\right)=\left(0.41 * 44.573 *\left(\mathrm{~V} / \mathrm{F}_{2}{ }^{0.783}\right) \mathrm{N}_{\mathrm{r}} * 2.0+\left(\mathrm{Q}_{\mathrm{D}}\right)_{\mathfrak{r}}\right.$

$\mathrm{Q}$, , $\mathrm{V}, \mathrm{F}_{\mathrm{a}}, \mathrm{N}_{\mathrm{r}}, \mathrm{D}$, and $\mathrm{ft}$ are as defined in equations (1), (2), and (5).

\section{Unit-Requirement Models}

The unit-use requirement models estimate future water demand as a product of projected WSA 
commercial and industrial employment and a value of per-employee water use. The unit-use coefficient is assumed to be fixed through time; that is, new technology is not a factor the model recognizes. Price elasticities are not factors in the models. Industrial water use is estimated as follows:

$$
\left(Q_{2}\right)_{n}=\left(C_{2}\right)_{n} * P_{n},
$$

where
a is average annual use;
n is industrial use category;
C is industrial water-use coefficient, in gallons per employee per day;
$P$ is water use parameter--employment; and
$Q$ is as defined in equation (1).

\section{Data Preparation/Model Input}

Housing and employment data were prepared as input to the water-use and socioeconomic models contained in the IWR-MAIN System. Several assumptions about the character of the data for the base and the calibration years and about the structure of socioeconomic conditions in future years were necessary to model the basin. These assumptions are detailed within the respective data sections.

The water-use models of the IWR-MAIN System used demographic and economic data provided externally by the user as well as parameter values generated internally by socioeconomic models in the system. Actual values of these parameters (table 7) are required for a base, or beginning year, and projected values of selected parameters for specified future years. The data were developed for each WSA (Bedford, Coffee, Marshall, and Maury) for the residential, commercial, and industrial sectors. This spatial disaggregation allowed the system to consider varying rates of sector growth within the basin, and to consider the effect of different rate structures on water use. Data were prepared for the base year, 1980; calibration year, 1989; and, future years, 1995, 2000, and 2015.
The socioeconomic models (referred to as housing or employment models) in the IWR-MAIN System generated future values for housing and employment. These models contain coefficients and elasticities developed from intensive statistical analyses of data sets representing a cross section of national housing and employment patterns (U.S. Army Corps of Engineers, 1988). Unlike the water-use models, these models are not calibrated by the user to reflect local socioeconomic conditions. Instead, data detailing local conditions are input to the IWR-MAIN System and override the parameter-generating algorithms.

For the purposes of this study, the base year (1980) and calibration year (1989) are two different years. Socioeconomic conditions had changed significantly between 1980 and 1989 and sufficient data were available for 1989 to calibrate that year. The quality of the water-use data also improved significantly from 1980 to 1989 . Whereas the 1980 water-use data were insufficient to ensure a reliable calibration, a water-use inventory for 1989 provided sufficient data to satisfy modeling requirements.

Some base-year data are required to calibrate the water-use models in this study and some are required by the socioeconomic models to quantify initial housing and employment conditions (table 7). At a minimum, a water-demand forecast requires the user to input total population, total employment, and median income for each future year. For this study, the number of housing units by type and employment statistics for several categories were projected externally and added to the system for the forecasts.

For the public/unaccounted sector and for the maximum-daily use dimension, water use was estimated externally to the system. Public/unaccounted water was calculated as a percentage of the total municipal water use (fig. 5). For the calibration year, the percentage reflects the unaccounted amount observed for the major public-water facility in each WSA; for the future years, the percentage remains constant through time for each WSA at 15 percent. This 15 percent is close to the default value for the 
IWR-MAIN System, 14.9 percent. For maximum daily water use, the ratio of maximum daily to annual average water use for 1988 (a drought year) (table 3) was applied to the total water use for the calibration and the future years. This estimated amount represents, therefore, maximum daily water use under drought conditions.

\section{Housing Data}

The residential sector of the IWR-MAIN System was disaggregated into two housing categories: MW and FP (fig. 5). For modeling the Duck River basin these housing categories were defined as follows:

- MW consists of specified, occupied housing units (housing units built on less than 10 acres of land without property attachment) (U.S. Department of Commerce, 1982a). These units are individually metered, but not necessarily sewered.

- The FP category was principally used to manage the housing-unit data that were not included in the MW category. It includes housing units which depend on domestic wells (self-supplied) for their water; nonspecified housing units [housing units situated on 10 acres or more or housing units attached to a commercial establishment (U.S. Department of Commerce, 1982a)]; and, mobile homes. FP water demand is not included in the municipal totals for water demand for the basin. FP water-use models were not calibrated for this study, because no actual water-use data existed to compare to a simulated water demand.

\section{Base- and Calibration-Year Data}

Several sources of data were used in preparing base-year input values required to construct the residential water-use models (table 7). The U.S. Census Bureau provided data enumerating: specified owner-occupied housing units by value range; renteroccupied units by range of contract rent; and occupied housing units in the county and urban areas served by public-supply systems or served by sewerage (U.S.
Department of Commerce, 1982a, 1983). The number of housing units by type (MW or FP) and value range that were input to the model for the base year 1980 resulted from the spatial analysis of these data sets (table 9). All renter-occupied units are included in the MW category. Renter-occupied units were combined with owner occupied units to yield total occupied units by value range. Contract rent was converted to housing value using the following equation:

$$
F=\frac{(1+i)^{N}}{i(1+i)^{N}}
$$

where

$F$ is conversion factor,

$i$ is 1980 discount rate, and

$\mathrm{N}$ is number of months in mortgage period.

Equivalent housing value expressed in 1980 dollars is as follows:

$$
\mathrm{V}=\mathrm{R} * \mathrm{~F}
$$

where

$\mathrm{V}$ is equivalent housing value, and

$R$ is monthly rent.

For the basin,

$$
\begin{aligned}
\mathrm{F} & =66.353, \\
\mathrm{i} & =0.015(18 \text { percent in } 1980), \text { and } \\
\mathrm{N} & =360 .
\end{aligned}
$$

For the calibration year (1989), estimates of the total number of occupied housing units by WSA were provided by the Tennessee Housing Development Agency (Linda Lavagia, oral commun., 1990). The type of decennial data (U.S. Department of Commerce, 1982a) used to disaggregate the housing units by type (MW or FP) for 1980 was not available for 1989; therefore, the same proportions as determined for the base year were used for 1989 (table 9).

Housing density (fig. 5, table 7) for the central part of the city of Columbia (David Holderfield, Director of Grants and Planning for the City of Columbia, oral commun., 1991) was used as the housing density value for each WSA for the base, calibration, and future years. This density value is 6 units per acre. Housing density in each WSA is low compared to 
Table 9. Number of occupied housing units by type

[WSA, Water-service area; MW, metered and sewered; FP, Flat rate with septic tank]

\begin{tabular}{|c|c|c|c|c|c|}
\hline \multirow{2}{*}{$\begin{array}{c}\text { WSA } \\
\text { Housing typo }\end{array}$} & \multicolumn{5}{|c|}{ Housing unlts } \\
\hline & 1980 & 1989 & 1995 & 2000 & 2015 \\
\hline \multicolumn{6}{|l|}{ Bedford } \\
\hline $\begin{array}{l}\text { MW } \\
\text { FP }\end{array}$ & $\begin{array}{l}6,713 \\
3,232\end{array}$ & $\begin{array}{l}8,060 \\
3,880\end{array}$ & $\begin{array}{r}10,519 \\
2,034\end{array}$ & $\begin{array}{r}12,028 \\
1,060\end{array}$ & $\begin{array}{r}14,240 \\
593\end{array}$ \\
\hline \multicolumn{6}{|l|}{ Coffee } \\
\hline $\begin{array}{l}\text { MW } \\
\text { FP }\end{array}$ & $\begin{array}{r}10,401 \\
3,249\end{array}$ & $\begin{array}{r}12,489 \\
3,944\end{array}$ & $\begin{array}{r}14,916 \\
2,034\end{array}$ & $\begin{array}{r}16,348 \\
1,043\end{array}$ & $\begin{array}{r}18,227 \\
564\end{array}$ \\
\hline \multicolumn{6}{|l|}{ Marshall } \\
\hline $\begin{array}{l}\text { MW } \\
\text { FP }\end{array}$ & $\begin{array}{l}5,215 \\
1,929\end{array}$ & $\begin{array}{l}6,351 \\
2,350\end{array}$ & $\begin{array}{l}7,361 \\
1,727\end{array}$ & $\begin{array}{r}8,639 \\
854\end{array}$ & $\begin{array}{r}10,222 \\
487\end{array}$ \\
\hline \multicolumn{6}{|l|}{ Maury } \\
\hline $\begin{array}{l}\text { MW } \\
\text { FP }\end{array}$ & $\begin{array}{r}14,499 \\
2,792\end{array}$ & $\begin{array}{r}15,875 \\
3,131\end{array}$ & $\begin{array}{r}19,313 \\
1,566\end{array}$ & $\begin{array}{r}20,943 \\
647\end{array}$ & $\begin{array}{r}23,165 \\
716\end{array}$ \\
\hline
\end{tabular}

housing density in the urban areas where most of the municipal water is delivered. Because the model uses housing density to calculate the amount of irrigable land, equation 3, and ultimately summer demand, a high housing density was necessary for each WSA to calibrate the expected summer usage.

The model is structured so that only one value for the housing density variable for the base, calibration, and future years can be specified for each model run. Changing the housing density value creates an alternative water-use scenario. Model input for the pricing and the climate variables have the same limits, wherein each pricing and climate specification represents a new set of model conditions and a different water-use scenario.

The U.S. Census Bureau provided statistics for resident population (fig. 5, table 7) for each WSA for the base year (1980). The Department of Sociology, University of Tennessee, projected resident population for the calibration year (1989) (B.B. Vickers, University of Tennessee, 1990). Future-year projections resulted from the application of the growth equation to the 1980 census data and the 1990 preliminary census data (April 1990) (Appendix B) as follows:

where

$$
\mathrm{POPU}_{\mathrm{f}}=\mathrm{POPU} * \mathrm{e}^{\mathrm{kt}},
$$

$\mathrm{POPU}_{\mathrm{f}}$ is future year population,

POPU is population as of 1980 ,

e is the base of the natural logarithm

$k$ is growth constant, and

$t$ is projection time interval.

An inventory of water- and wastewater-rate structures for each system in each WSA was used to specify annual, summer season, and marginal price, 
and to calculate bill difference for the base year (tables 7 and 10, and fig. 5). Rate-structure information for the period 1980-90 was compiled and the rates were expressed in 1980 constant dollars. The annual inventory of water- and wastewater-rate structures by Allen and Hoshall Consultants, provided supplemental rate data (1980 to 1990) (Allen and Hoshall Consultants, written commun., 1991).

Table 10. Marginal price and bill difference in 1980 dollars for the metered and sewered housing category

\begin{tabular}{lccc}
\hline $\begin{array}{l}\text { Water- } \\
\text { service } \\
\text { area }\end{array}$ & $\begin{array}{c}\text { Annual price } \\
\text { per thousand } \\
\text { gallons }\end{array}$ & $\begin{array}{c}\text { Marginal price } \\
\text { per thous and } \\
\text { gallons }\end{array}$ & $\begin{array}{c}\text { Bill difference } \\
\text { per thous and } \\
\text { gallons }\end{array}$ \\
\hline Bedford & 8.69 & 6.08 & 1.64 \\
Coffee & 2.89 & 2.59 & 4.57 \\
Marshall & 3.21 & 3.13 & 1.27 \\
Maury & 1.80 & 1.65 & 3.78 \\
\hline
\end{tabular}

The rate structure imposed by the largest public supplier in each WSA was adopted as the determining rate structure for water demand in that WSA (table 10). Either this public supplier served most of the connections in the WSA or it distributed water to other systems, influencing their rate structure. The selected systems were Columbia Water Department (Maury WSA), Lewisburg Water System (Marshall WSA), Shelbyville Water System (Bedford WSA), and Tullahoma Utility Board (Coffee WSA).

\section{Future-Year Data}

For the future years (1995, 2000, and 2015), the number of total housing units was generated externally to the IWR-MAIN System (fig. 5, table 7). The external method uses the projected resident population for each future year and divides by the number of persons per household in 1990 (U.S. Census Bureau, written commun., 1990) (Appendix B). To project the number of housing units by type for each simulation interval (1989 to 1995; 1995 to 2000; and 2000 to 2015), the percent of FP housing units was decreased by about 50 percent (table 9). For example, for the Bedford WSA, the FP housing units are 32.5 percent of the total housing units. For the first simulation interval (1989 to 1995), the percentage of FP units was reduced to 16.2 percent; the next interval (1995 to 2000), 8 percent; and the last interval (2000 to 2015), 4 percent. This reduction quantifies a water-use scenario reflecting an assumed rate of expansion for the public-supply systems and a corresponding rate of decrease for domestic self-supplied water within each WSA. This scenario also assumes that in the future none of the WSA's will be 100-percent supplied by public water.

For the calibration and future years, the number of housing units within a selected value range for a specified housing type (MW or FP) were generated by an internal econometric housing model (fig. 5, table 7). In calculating the percent of housing units for a selected value range, this housing model considered the rate of changes in median income and in population from the base year to the future year (U.S. Army Corps of Engineers, 1988) (table 11).

The only complete assessment of median household income in Tennessee occurs in each decennial census (fig. 5, table 7). The 1980 Census provided base year (1980) median household income. For the calibration and future years, median household income was projected using a multiplier derived from the average of the rate of change in per capita income in constant 1972 dollars projected by the Bureau of Economic Analysis, U.S. Department of Commerce (1988) (table 12). Six rates of change were projected from 1980 to 2015 . These projected rates of change were used in conjunction with the 1979 median household income for each county as reported by the U.S. Census Bureau in 1980, which enabled the projection to be expressed in constant 1979 dollars. The multiplier was used as a measure of expected growth in median household income through the year 2015. The projected rates of change in per capita income ranged from 0.003 (1980-83) to 0.031 (1983-89) (Charles Brown, Director of Tennessee Data Center, oral commun., 1991). 
Table 11. Projected metered and sewered occupied housing units by value range

[WSA, water-eervice area]

W8A

Volue range.

in $\$ 1,000$

(1980 constant dollare)
Housing units

\begin{tabular}{llll}
\hline 1989 & 1995 & 2000 & 2015
\end{tabular}

Bedford

$$
\begin{array}{rr}
0.0 & -10.0 \\
10.0 & -20.0 \\
20.0 & -30.0 \\
30.0 & -50.0 \\
50.0 & -100.0 \\
100.0 & -150.0 \\
150.0 & -200.0 \\
200.0 & -200.1
\end{array}
$$

Coffee

$\begin{array}{rr}1,877 & 1,889 \\ 1,240 & 1,248 \\ 1,096 & 1,103 \\ 1,667 & 1,979 \\ 1,238 & 1,995 \\ 789 & 1,930 \\ 102 & 249 \\ 51 & 125\end{array}$

2,363

2,110

1,248

2,657

2,824

1,139

117

31
2,117

1,891

1,118

2,887

4,183

2,407

247

66

1,407

932

852

1,125

1,351

1,420

109

164
1,739

1,150

1,016

2,055

2,518

2,974

384

192

1,826

1,631

964

2,863

5,059

3,544

364

97

1,379

914

836

1,223

1,683

2,185

168

252
395

261

231

1,922

4,171

6,082

785

426

378

337

199

2,411

7,748

6,330

650

173

$150.0-200.0$

$200.0-200.1$

Maury

$\begin{array}{rr}0.0 & -10.0 \\ 10.0 & -20.0 \\ 20.0 & -30.0 \\ 30.0 & -50.0 \\ 50.0 & -100.0 \\ 100.0 & -150.0 \\ 150.0 & -200.0 \\ 200.0 & -200.1\end{array}$

2,465

3,186

1,644

3,166

3,073

1,788

347

206
2,181

2,819

1,455

3,467

4,406

3,809

739

439
1,928

2,493

1,286

3,475

4,973

5,185

1,006

597
317

210

192

1,167

2,818

4,628

356

534 
Table 12. Median household income

[WSA, water-service area]

\begin{tabular}{llllll}
\hline \multirow{2}{*}{ WSA } & \multicolumn{5}{c}{$\begin{array}{c}\text { Medien household income, } \\
\text { in 1980 constant dollers }\end{array}$} \\
\cline { 2 - 6 } & 1980 & 1989 & 1995 & 2000 & 2015 \\
\hline Bedford & 13,757 & 16,671 & 18,699 & 20,343 & 25,035 \\
Coffee & 14,331 & 17,366 & 19,479 & 21,191 & 26,077 \\
Marshall & 13,523 & 16,387 & 18,381 & 19,997 & 24,608 \\
Maury & 14,726 & 17,844 & 20,015 & 21,561 & 26,040 \\
& & & & & \\
\hline
\end{tabular}

\section{Employment Data}

For the commercial sector, several SIC categories are grouped into one because the water-use coefficients for the categories are similar. For industry, a more comprehensive data base and a greater range of values for coefficients for the categories resulted in more disaggregation of the industrial categories than of the commercial categories. The number of commercial employment categories for the four WSA's range from 4 to 11 . The number of categories for industry range from 13 to 30 (table 13).

\section{Base- and Calibration-Year Data}

The water-use models require employment statistics at the 3-digit SIC level for the commercial and industrial sectors whereas the employment model only requires this level of disaggregation for the base year. The most comprehensive data are published at the 2-digit SIC level by the Tennessee Department of Employment Security (1990, 1991). The U.S. Census of Population and Housing for 1980 (U.S. Department of Commerce, 1982b) provides total employment and employment by 2-digit SIC category for each WSA for the base year 1980. Employment statistics are sparse at the 3-digit SIC level. An unpublished water-use inventory (Tennessee Division of Water Supply, computer files, 1981) for 1980 enabled some disaggregation of industrial water users by 3-digit SIC code. In one major water-use category, metals and machinery (SIC 33), only about 25 percent of the employees were identified at the 3-digit SIC level. Therefore, the remaining employees (SIC 33) were assigned to a 3-digit SIC category that reflected the average water use per employee for the 2-digit category (U.S. Army Corps of Engineers, 1988).

The employment model requires total employment data for each WSA for 5 years before the base year, the base year, the calibration year, and each future year. The State Labor Force Summary provided total employment statistics from 1975 (5 years before the base year) to 1989 (Tennessee Department of Employment Security, 1990). The industrial water-use inventory conducted by TDWS in 1989 (U.S. Geological Survey unpublished data, 1990), the Directory of Manufacturers (White, 1989), the Community Economic Data publications (Tennessee Department of Economic and Community Development, 1988; 1989a; 1989b; 1989c; 1990), and Tennessee labor force estimates from the Tennessee Department of Employment Security (1990) provided a means of disaggregating the 2-digit employment water-use estimates, statistics to 3-digit statistics. For the calibration year water-use estimates, employment is disaggregated into 3-digit SIC categories.

\section{Future-Year Data}

Regression analysis predicted total employment for each WSA for 1995, 2000, and 2015 (Appendix C) (fig. 5, table 7). Information detailing plant closings, expansions, or initiations determined from 1990 industrial data were used to externally project changes to employment statistics in the 3-digit SIC categories. For those SIC categories for which no growth information was available, the employment model generated the future year statistics. The employment model reviews changes in total employment implied by base year and future year data to establish a compound rate of growth. Employment projections for each of the simulation periods result from applying this growth rate to the base-year employment total.

\section{Model Calibration}

Model calibration consists of inputting actual socioeconomic data for a period of time and simulating water use by various sectors of the municipal system. Actual water use is compared to simulated results to 
Table 13. Model and calibration coefficients by employment categories for the Institute for Water Resources-Municipal and Industrial Needs System

[NC, no change to model coefficient; SIC, Standard Industrial Classification; values, in gallons per day per employee; -, not applicable]

\begin{tabular}{|c|c|c|c|c|c|c|}
\hline \multirow{2}{*}{ Catogory } & \multirow{2}{*}{ SIC } & \multirow{2}{*}{$\begin{array}{l}\text { Modal } \\
\text { coofficient }\end{array}$} & \multicolumn{4}{|c|}{$\begin{array}{l}\text { Colibration } \\
\text { coofficiont }\end{array}$} \\
\hline & & & Bodford & Coffoe & Marshall & Moury \\
\hline \multicolumn{7}{|c|}{ Commercial sector } \\
\hline $\begin{array}{l}\text { Miscellaneous } \\
\text { commercial. }\end{array}$ & - & 47.2 & 19.1 & 24.1 & 167.0 & 248.0 \\
\hline $\begin{array}{l}\text { Barbers and } \\
\text { cleaning. }\end{array}$ & - & 380.2 & 190.1 & NC & NC & NC \\
\hline $\begin{array}{l}\text { Recreational } \\
\text { facilities. }\end{array}$ & - & 225.5 & 167 & NC & NC & NC \\
\hline $\begin{array}{l}\text { Hotels and } \\
\text { restaurants. }\end{array}$ & - & 186.6 & 93 & 54.1 & NC & NC \\
\hline Parks & - & 720.7 & $\mathrm{NC}$ & NC & 21,000 & NC \\
\hline Government & - & 70.6 & 35.3 & 35.3 & NC & NC \\
\hline Utilities & - & 6.7 & NC & NC & NC & 20 \\
\hline \multicolumn{7}{|c|}{ Industrial sector } \\
\hline Meat products & 201 & 343.8 & 331 & NC & NC & NC \\
\hline Dairy products & 202 & 354.4 & NC & NC & 1,505 & NC \\
\hline Beverages & 208 & 691.4 & NC & 200 & NC & NC \\
\hline Paperboard & 265 & 91.3 & NC & NC & 112 & NC \\
\hline Plastics & 282 & 333.3 & NC & NC & 363 & NC \\
\hline Soap & 284 & 283.1 & NC & NC & 19 & NC \\
\hline Paints & 285 & 254.7 & NC & NC & 130 & 1,329 \\
\hline $\begin{array}{l}\text { Agricultural } \\
\text { chemicals. }\end{array}$ & 287 & 839.9 & NC & NC & NC & 1,650 \\
\hline Rubber products & 306 & 144.9 & NC & NC & 152.5 & $\mathrm{NC}$ \\
\hline Plastics & 307 & 206.2 & 200 & 68 & 152.5 & 2,034 \\
\hline Footwear & 314 & 60.1 & $\mathrm{NC}$ & NC & 20 & NC \\
\hline Concrete & 327 & 183.8 & NC & NC & 1,134 & 440.3 \\
\hline Nonmetallics & 329 & 156.6 & NC & NC & NC & 375.1 \\
\hline Nonferrous & 335 & 303.0 & NC & NC & NC & 479 \\
\hline rolling. & 336 & 184.8 & NC & NC & 70 & NC \\
\hline $\begin{array}{l}\text { Nonferrous } \\
\text { foundry. }\end{array}$ & 345 & 122.4 & NC & NC & 46 & NC \\
\hline Metal services & 347 & 425.3 & NC & NC & 380.8 & NC \\
\hline Fabricated metal & 349 & 102.6 & NC & NC & 47 & NC \\
\hline Metalworking & 354 & 41.9 & NC & NC & 18.6 & NC \\
\hline Machinery & 358 & 139.7 & NC & NC & 124 & 190 \\
\hline Electrical & 362 & 189.9 & NC & NC & $\mathrm{NC}$ & 1,379 \\
\hline Vehicles & 371 & 217.9 & 200 & NC & 51.8 & NC \\
\hline Boat building & 373 & 110.1 & NC & 57 & $\mathrm{NC}$ & NC \\
\hline Toys & 394 & 110.9 & NC & 69 & $\mathrm{NC}$ & NC \\
\hline Pens and pencils & 395 & 102.4 & NC & NC & 43.3 & NC \\
\hline Miscellaneous & 399 & 93.9 & NC & 69 & NC & 9,600 \\
\hline
\end{tabular}


determine calibration accuracy. Two major steps comprise the calibration process:

(1) Initial simulation using all the default parameters of the IWR-MAIN System; and

(2) Analysis of the pattern of errors resulting when the simulated water demand is compared to the actual values, then adjusting equations as needed.

The year 1989 was selected for calibration because water use was inventoried for the public-supply systems and industries in the upper Duck River basin for that year. The water-use inventory provided a guide to adjusting the residential, commercial, and industrial constants and coefficients of the water-use models (tables 13 and 14).

Table 14. Model and calibration constants for the metered and sewered housing models

\begin{tabular}{llrllll}
\hline $\begin{array}{l}\text { Metered } \\
\text { and } \\
\text { sewered } \\
\text { housing } \\
\text { models }\end{array}$ & $\begin{array}{c}\text { Model } \\
\text { constant }\end{array}$ & & \multicolumn{4}{c}{$\begin{array}{c}\text { Calibration } \\
\text { constant }\end{array}$} \\
\cline { 3 - 7 } & & Bedford & Coffee & Marshall & Maury \\
\hline Winter season & 234 & 541 & 217 & 294 & 235 \\
Summer season & 385 & 2,407 & 241 & 829 & 385 \\
\hline
\end{tabular}

For this study, the IWR-MAIN System estimates of the residential water demand for each season exhibit a systematic error of overpredicting (or underpredicting) actual water use in the calibration year. The percent error is approximately the same for all years within each WSA. This pattern of prediction error indicates that residential water use in the study area is characterized by a higher (or lower) base use than that observed in the data that were used to derive the IWRMAIN System demand models. A systematic error of overpredicting water use was noted in the Coffee WSA (table 15). In contrast, the simulated residential water demand for the Bedford, Marshall, and Maury WSA's was consistently lower. The simulated water demand for the Maury WSA was slightly less than the actual residential water use.
The winter and summer equation constants ( $y$ intercepts) representing gallons per household per day were adjusted to calibrate the seasonal models. Summer and annual water usage for each WSA were calibrated to yield a ratio of about 1.04 to agree with the summer (May-August) and annual ratio for the Columbia Water System for 1989 (fig. 4). Columbia Water System closely mirrored the seasonal water use of the other major water systems in the basin.

For the industrial and commercial unit-use requirement models, the results of the initial calibration revealed the need to adjust the IWR-MAIN System default coefficients from the Library of Coefficients (U.S. Army Corps of Engineers, 1988). The coefficient defining the per employee water use in various commercial and industrial categories (table 13) required adjustment, with the commercial sector requiring the greatest adjustments. Per employee rates of use for the largest utility customers were verified using the data compiled from the 1989 survey. These included industries with high employment, high projected rate of growth, or large quantity users. Changes to the coefficients reflect local per employee use for a specific SIC or represent average employee use for aggregated SIC categories (table 13).

\section{Model Reliability}

The constants, coefficients, and elasticities in the water-use models were generally reliable in estimating residential water demand. For two of the WSA's, the

Table 15. Observed and modeled average annual water demand for metered and sewered housing for 1989

[Mgal/d, million gallons per day]

\begin{tabular}{lccc}
\hline $\begin{array}{c}\text { Water-service } \\
\text { area }\end{array}$ & $\begin{array}{c}\text { Observed } \\
\text { value } \\
\text { (Mgal/d) }\end{array}$ & $\begin{array}{c}\text { Simulated water } \\
\text { demand without } \\
\text { adjustments } \\
\text { (Mgal/d) }\end{array}$ & $\begin{array}{c}\text { simulated water } \\
\text { demand with } \\
\text { adjustments } \\
\text { (Mgal/d) }\end{array}$ \\
\hline Bedford & 1.64 & -0.89 & 1.64 \\
Coffee & 1.90 & 2.30 & 1.90 \\
Marshall & 1.36 & .92 & 1.36 \\
Maury & 3.48 & 3.46 & 3.48 \\
\hline
\end{tabular}


pricing elasticities exceeded the model values. For the Bedford WSA, water rates exceeded the range of the pricing elasticities developed from the national data sets. A negative water demand $(-0.89 \mathrm{Mgal} / \mathrm{d})$ resulted (table 15). For the Marshall WSA, the calibration underpredicted water use by 32.4 percent. For both WSA's, a large adjustment to the y-intercept of the seasonal equations was made (table 14). The large adjustment to the y-intercept for the residential equations necessary to offset or counterbalance the low elasticities may create some concern about reliability of the model. The alternative is to develop extensive local data to calculate a local set of elasticities. The developers of the model recommend adjusting the equations by the methods described rather than attempting to develop local data with limited resources (Eva M. Opitz, Planning and Management Consultants, Ltd., oral commun., 1991).

The housing model calculates the percent change in number of housing units within a value range based on the percent change in median income and in population from the base year to the future year. This relation between housing units and median income is the least reliable factor in this study and, therefore, open to question. The projected median income is based on projected per capita income (table 12). These two measures of income are not the same. Per capita income was used in this study because it was the best available projected income data. In Maury County, the percent change in projected median income from 1989 to 2015 was about 77 percent $(\$ 14,726$ to $\$ 26,040)$ (table 12). Although the constant dollar amount was small $(\$ 11,314)$, the percent change in the housing value range, 100.0-150.0 thousand dollars, was large enough that the shift was significant (table 11). For 1980 , about 1 percent of the MW housing units were in this range; for 2015, 38.6 percent of the $\mathrm{MW}$ housing units were in this range. As demonstrated in equation 1, as housing value increases, water use increases. In the Maury WSA, per capita water use increased 38.9 percent [ 35 gallons per day (gal/d) from 1989 to 2015 (from 88 to $123 \mathrm{gal} / \mathrm{d}$ )] (table 16).
However, overall comparisons of the simulated residential water demand for the basin are acceptable and represent the specified model assumptions.

Table 16. Per capita use for the residential sector

\begin{tabular}{lcccr}
\hline \multirow{2}{*}{$\begin{array}{l}\text { Water } \\
\text { service } \\
\text { area }\end{array}$} & \multicolumn{4}{c}{ Per capita use, in gallons per pereon per day } \\
\cline { 2 - 5 } & 1989 & 1995 & 2000 & 2015 \\
\hline Bedford & 80 & 91 & 98 & 120 \\
Coffee & 62 & 70 & 75 & 89 \\
Marshall & 86 & 91 & 102 & 129 \\
Maury & 88 & 99 & 106 & 123 \\
\hline
\end{tabular}

\section{Results of Simulation}

The calibrated models of the IWR-MAIN System were used to simulate water demand in the upper Duck River basin for the years 1995, 2000, and 2015. The results of the simulation (table 17) show that:

- Total average water demand in the basin could increase 19 percent by year 1995, 39 percent by year 2000 , and 91 percent by year 2015 . The largest increases could occur in the Maury WSA (112 percent);

- Residential demand by year 2015 could increase 122 percent, with the largest increase in the Bedford WSA (162 percent);

- Industrial demand by year 2015 could increase 93 percent, with the largest increase in the Maury WSA (114 percent); and

- Commercial demand could increase 82 percent, with the largest increase in the Maury WSA (115 percent).

Maximum daily water demand could increase 91 percent, with the largest potential increases in the Maury WSA (112 percent) followed by the Marshall WSA (100 percent). 
Table 17. Simulated water demand, upper Duck River basin, by sector for 1989, 1995, 2000, and 2015

[Mgal/d, million gallons per day; WSA, water-service area]

\begin{tabular}{|c|c|c|c|c|c|}
\hline Sector & $\begin{array}{c}1989 \\
\text { (Mgal/d) }\end{array}$ & $\begin{array}{c}1995 \\
\text { (Mgal/d) }\end{array}$ & $\begin{array}{c}2000 \\
\text { (Mgal/d) }\end{array}$ & $\begin{array}{c}2015 \\
\text { (Mgal/d) }\end{array}$ & $\begin{array}{c}\text { Percent } \\
\text { change } \\
2015 \text { over } \\
1989\end{array}$ \\
\hline
\end{tabular}

\begin{tabular}{|c|c|c|c|c|c|}
\hline \multicolumn{6}{|c|}{ Bedford WSA } \\
\hline Residential & 1.64 & 2.41 & 2.97 & 4.29 & 162 \\
\hline Industrial & .96 & 1.06 & 1.18 & 1.54 & 60.0 \\
\hline Commercial & .19 & .20 & .21 & .26 & 36.8 \\
\hline Public/unaccounted & 1.58 & .65 & .77 & 1.07 & -32.0 \\
\hline Total sector use & 4.37 & 4.32 & 5.13 & 7.16 & 63.8 \\
\hline $\begin{array}{l}\text { Percentage public/ } \\
\text { unaccounted. }\end{array}$ & 36.10 & 15.00 & 15.00 & 15.00 & -58.4 \\
\hline Maximum daily & 6.44 & 6.35 & 7.54 & 10.53 & 63.5 \\
\hline \multicolumn{6}{|c|}{ Coffee WSA } \\
\hline Residential & 1.90 & 2.54 & 3.00 & 3.98 & 109 \\
\hline Industrial & .50 & .54 & .58 & .70 & 40.0 \\
\hline Commercial & .50 & .53 & .55 & .61 & 22.0 \\
\hline Public/unaccounted & .93 & .64 & .73 & .93 & 0.0 \\
\hline Total sector use & 3.83 & 4.25 & 4.86 & 6.22 & 62.4 \\
\hline $\begin{array}{l}\text { Percentage public/ } \\
\text { unaccounted. }\end{array}$ & 22.00 & 15.00 & 15.00 & 15.00 & -31.8 \\
\hline Maximum daily & 5.55 & 6.16 & 7.05 & 9.02 & 62.5 \\
\hline \multicolumn{6}{|c|}{ Marshall WSA } \\
\hline Residential & 1.36 & 1.78 & 2.24 & 3.31 & 143 \\
\hline Industrial & .61 & .69 & .79 & 1.03 & 68.9 \\
\hline Commercial & .22 & .26 & .30 & .41 & 86.0 \\
\hline Public/unaccounted & .63 & .49 & .60 & .88 & 39.7 \\
\hline Total sector use & 2.82 & 3.22 & 3.93 & 5.63 & 99.6 \\
\hline $\begin{array}{l}\text { Percentage public/ } \\
\text { unaccounted. }\end{array}$ & 22.30 & 15.00 & 15.00 & 15.00 & -32.7 \\
\hline Maximum daily & 4.29 & 4.89 & 5.97 & 8.56 & 99.5 \\
\hline \multicolumn{6}{|c|}{ Maury WSA } \\
\hline Residential & 3.48 & 4.74 & 5.44 & 7.06 & 103 \\
\hline Industrial & 3.57 & 4.27 & 5.10 & 7.64 & 114 \\
\hline Commercial & 1.11 & 1.64 & 1.79 & 2.39 & 115 \\
\hline Public/unaccounted & 1.25 & 1.88 & 2.08 & 2.88 & 130 \\
\hline Total sector use & 9.41 & 12.53 & 14.41 & 19.97 & 112 \\
\hline $\begin{array}{l}\text { Percentage public/ } \\
\text { unaccounted. }\end{array}$ & 13.30 & 15.00 & 15.00 & 15.00 & 12.8 \\
\hline Maximum daily & 14.49 & 19.30 & 21.30 & 29.60 & 112 \\
\hline
\end{tabular}


Table 17. Simulated water demand, upper Duck River basin, by sector for 1989, 1995, 2000, and 2015--Continued

\begin{tabular}{lccccc}
\hline \multicolumn{1}{c}{ Sector } & $\begin{array}{c}1989 \\
\text { (Mgal/d) }\end{array}$ & $\begin{array}{c}1995 \\
\text { (Mgal/d) }\end{array}$ & $\begin{array}{c}2000 \\
\text { (Mgal/d) }\end{array}$ & $\begin{array}{c}2015 \\
\text { (Mgal/d) }\end{array}$ & $\begin{array}{c}\text { Percent } \\
\text { change } \\
2015 \text { over } \\
\text { 1989 }\end{array}$ \\
\hline & \multicolumn{1}{c}{ Upper Duck } & & \\
Residential & 8.38 & 11.47 & 13.65 & 18.64 & 122 \\
Industrial & 5.64 & 6.56 & 7.65 & 10.91 & 93.4 \\
Commercial & 2.02 & 2.63 & 2.85 & 3.67 & 81.7 \\
Public/unaccounted & 4.39 & 3.66 & 4.18 & 5.76 & 31.2 \\
Total demand & 20.43 & 24.32 & 28.33 & 38.98 & 90.8 \\
Maximum daily & 30.77 & 36.70 & 42.75 & 58.86 & 91.3 \\
\hline
\end{tabular}

\section{EFFECT OF WATER WITHDRAWALS ON STREAMFLOW}

The effect of current and future municipal water withdrawals on streamflow in the upper Duck River was estimated at 11 locations from Normandy Dam to Columbia (fig. 7, table 18). A water budget for withdrawals and inflow discharges was calculated for two operational flow scenarios. The first scenario was for a summer minimum discharge of $155 \mathrm{ft}^{3} / \mathrm{s}$ (100.2 Mgal/d); the second for a winter minimum discharge of $120 \mathrm{ft}^{3} / \mathrm{s}(77.6 \mathrm{Mgal} / \mathrm{d})$. The operational flows are measured at the USGS gage at Shelbyville. Projections show that simulated water demands and flows at key sites would be as follows:

- For an operational flow of $155 \mathrm{ft}^{3} / \mathrm{s}$ (100.18 Mgal/d) at Shelbyville, flow at Columbia would be $134 \mathrm{ft}^{3} / \mathrm{s}$ (87.6 Mgal/d) in 1995; $130 \mathrm{ft}^{3} / \mathrm{s}(85.0 \mathrm{Mgal} / \mathrm{d})$ in 2000 ; and $119 \mathrm{ft}^{3} / \mathrm{s}$ $(77.8 \mathrm{Mgal} / \mathrm{d})$ for year 2015 .

- For an operational flow of $120 \mathrm{ft}^{3} / \mathrm{s}$ (77.56 Mgal/d) at Shelbyville, flow at Columbia would be $99.0 \mathrm{ft}^{3} / \mathrm{s}(65.0 \mathrm{Mgal} / \mathrm{d})$ in 1995 ; $95.0 \mathrm{ft}^{3} / \mathrm{s}(62.4 \mathrm{Mgal} / \mathrm{d})$ in 2000; and $83.7 \mathrm{ft}^{3} / \mathrm{s}$ (55.2 Mgal/d) in 2015.

\section{SUMMARY}

The upper Duck River basin includes an area of about 1,700 square miles in Coffee, Bedford, Marshall, Maury Counties, and part of southern Williamson County in Middle Tennessee. Duck River, which is the principal source of municipal water supplies in the basin, has been regulated since 1976 at Normandy Reservoir. The reservoir, located in the headwaters of the basin near Tullahoma, is used for flood control, water-quality enhancements, low-flow augmentation, water supply, and recreation.

Water use in the basin increased 16 percent from 1980 to $1990(18.0 \mathrm{Mgal} / \mathrm{d}$ to $20.9 \mathrm{Mgal} / \mathrm{d})$. Socioeconomic data for the area suggest that water demands will continue to increase in response to residential, industrial, and commercial development. Officials from the Upper Duck River Development Authority and the Tennessee State Planning Office are concerned about the capacity of the river to meet future water demands. In an attempt to address this concern, an investigation was conducted by the USGS from 1989 to 1991 to determine water use and availability in the basin and potential future water demands. The study also included an overview of the potential for developing the ground-water resources in the area. 

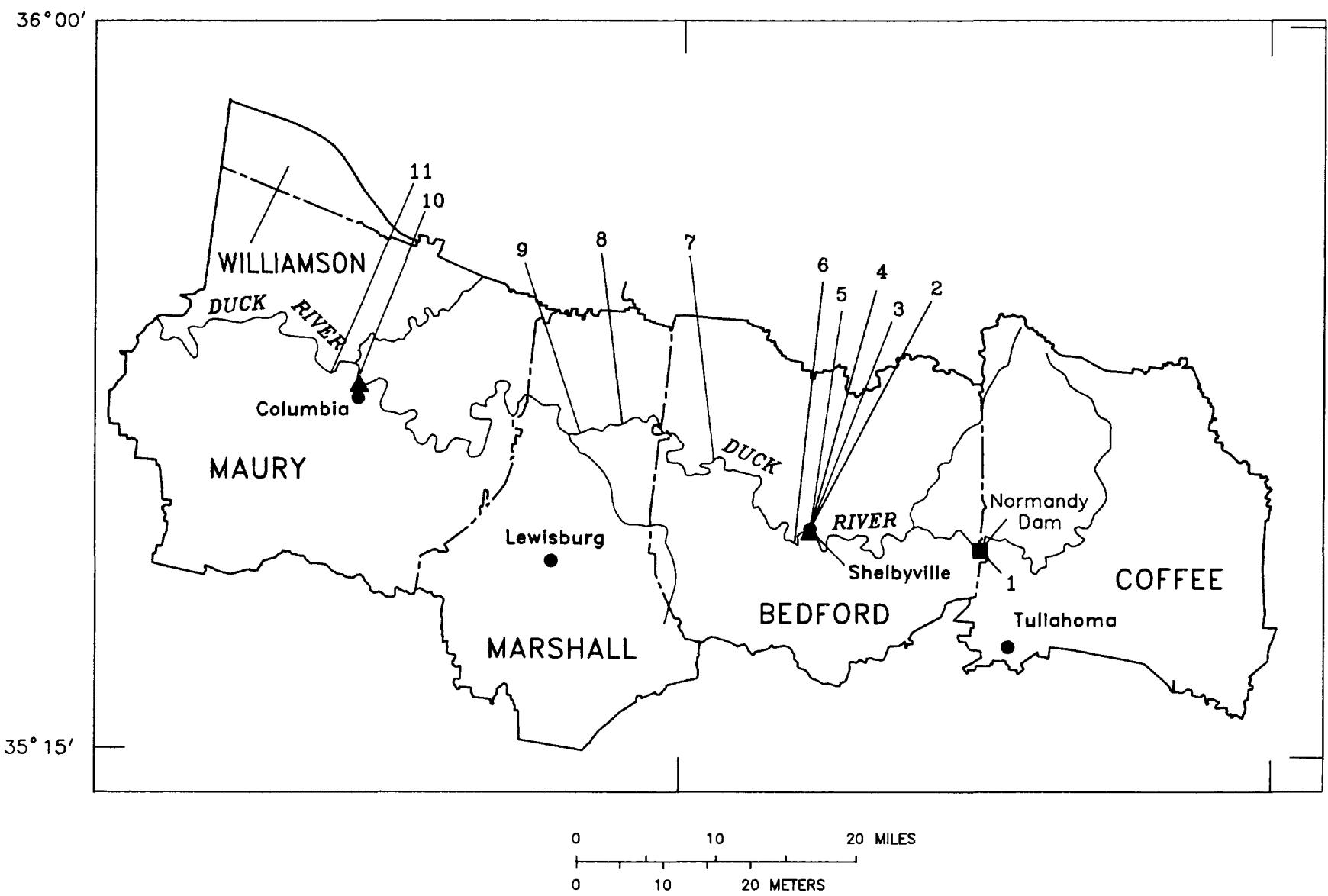

\section{EXPLANATION}

STUDY-AREA BOUNDARY

WATER-SERVICE-AREA BOUNDARY--Each county water-service area is consistent with that county's political boundary, except for the

Maury County water-service area that also

includes part of southern Williamson County

- CONTINUOUS STREAMFLOW-GAGING STATION

1 SITE NUMBER

Figure 7. Water withdrawal and inflow discharge sites along the Duck River. 
Table 18. Effect of water withdrawals and inflow discharges at various locations along the upper Duck River

[ $\mathrm{t}^{3} / \mathrm{s}$, cubic feet second; Mgal/d, million gallons per day; 1 cubic foot per second $=0.646317 \mathrm{Mgal} / \mathrm{d} ;-$, withdrawal; + , diecharge; - , no tranaction. Site is a geographic reference point; aite location: 1, Normandy Dam; 2, Shelbyville Water Syatem (intake); 3, Shelbyville Water Syatem (diecharge); 4, U.S. Geological Survey gage; 5, Shelbyville Sewer Department; 6, industry; 7, Bedford County Utility District; 8, Chapel Hill Sewer Syatem; 9, Lewisburg Water System; 10, U.S. Geological Survey gage; 11, Columbia Water Department]

\begin{tabular}{|c|c|c|c|c|c|c|c|c|c|}
\hline \multirow{2}{*}{$\begin{array}{l}\text { site } \\
\text { number } \\
\text { (see } \\
\text { flg. } 7 \text { ) }\end{array}$} & \multirow[b]{2}{*}{$\begin{array}{l}\text { River } \\
\text { mile }\end{array}$} & \multicolumn{2}{|c|}{1989} & \multicolumn{2}{|c|}{1995} & \multicolumn{2}{|c|}{2000} & \multicolumn{2}{|c|}{2015} \\
\hline & & $\begin{array}{c}\text { Water } \\
\text { use } \\
\text { (Mgal/d) }\end{array}$ & $\begin{array}{c}\text { Flow } \\
\text { (Mgai/d) }\end{array}$ & $\begin{array}{c}\text { Water } \\
\text { use } \\
\text { (Mgal/d) }\end{array}$ & $\begin{array}{c}\text { Flow } \\
\text { (Mgal/d) }\end{array}$ & $\begin{array}{c}\text { Water } \\
\text { use } \\
\text { (Mgol/d) }\end{array}$ & $\begin{array}{l}\text { Flow } \\
\text { (Mgal/d) }\end{array}$ & $\begin{array}{c}\text { Wator } \\
\text { use } \\
\text { (Mgal/d) }\end{array}$ & $\begin{array}{c}\text { Flow } \\
\text { (Mgal/d) }\end{array}$ \\
\hline
\end{tabular}

Summer operational flow, $155 \mathrm{ft}^{3} / \mathrm{s}(100.18 \mathrm{Mgal} / \mathrm{d})$, at river mile 221.4

$\begin{array}{rrrrrrrrrr}1 & 248.6 & - & 103.40 & - & 103.37 & - & 104.18 & - \\ 2 & 222.0 & -3.22 & 100.18 & -3.19 & 100.18 & -4.00 & 100.18 & -6.03 & 100.18 \\ 3 & 221.9 & +.06 & 100.24 & +.06 & 100.24 & +.06 & 100.24 & +.21 \\ 4 & 221.4 & - & 100.24 & - & 100.24 & - & 100.24 & 100.24 \\ 5 & 221.3 & +1.79 & 102.03 & +1.79 & 102.03 & +1.79 & 102.03 & 100.24 \\ 6 & 220.2 & +.80 & 102.83 & +.80 & 102.83 & +.80 & 102.83 & +1.79 & 102.03 \\ 7 & 202.4 & -.68 & 102.15 & -.68 & 102.15 & -.68 & 102.15 & +.80 & 102.83 \\ 8 & 185.5 & +.20 & 102.35 & +.20 & 102.35 & +.20 & 102.35 & -.68 & 102.15 \\ 9 & 181.0 & -2.71 & 99.64 & -3.11 & 99.24 & -3.82 & 98.53 & -.20 & 102.35 \\ 10 & 136.9 & - & 99.64 & - & 99.24 & - & 98.53 & -5.52 & 96.83 \\ 11 & 133.7 & -8.48 & 91.16 & -11.60 & 87.64 & -13.48 & 85.05 & -19.04 & 77.79\end{array}$

Winter operational flow, $120 \mathrm{ft} / \mathrm{s}(77.56 \mathrm{Mgal} / \mathrm{d})$, river mile 221.4

\begin{tabular}{rlrlrlrlrr}
1 & 248.6 & - & 80.78 & - & 80.75 & - & 81.56 & - & 83.59 \\
2 & 222.0 & -3.22 & 77.56 & -3.19 & 77.56 & -4.00 & 77.56 & -6.03 & 77.56 \\
3 & 221.9 & +.06 & 77.62 & +.60 & 77.62 & +.60 & 77.62 & +.06 & 77.62 \\
4 & 221.4 & - & 77.62 & - & 77.62 & - & 77.62 & - & 77.62 \\
5 & 221.3 & +1.79 & 79.41 & +1.79 & 79.41 & +1.79 & 79.41 & +1.79 & 79.41 \\
6 & 220.2 & +.80 & 80.21 & +.80 & 80.21 & +.80 & 80.21 & +.80 & 80.21 \\
7 & 202.4 & -.68 & 79.53 & -.68 & 79.53 & -.68 & 79.53 & -.68 & 79.53 \\
8 & 185.5 & +.20 & 79.73 & +.20 & 79.73 & +.20 & 79.73 & +.20 & 79.73 \\
9 & 181 & -2.71 & 77.02 & -3.11 & 76.62 & -3.82 & 75.91 & -5.52 & 74.21 \\
10 & 136.9 & - & 77.02 & - & 76.62 & - & 75.91 & - & 74.21 \\
11 & 133.7 & -8.48 & 68.54 & -11.60 & 65.02 & -13.48 & 62.43 & -19.04 & 55.17 \\
\hline
\end{tabular}

The Duck River supplied an average of the balance (about 7 percent or $1.5 \mathrm{Mgal} / \mathrm{d}$ ) was sup18.9 Mgal/d in 1989 to utilities within four WSA's. plied from springs and wells. Normandy Reservoir The WSA's provide water for domestic, commercial, and industrial uses to Tullahoma, Manchester, Lewisburg, Shelbyville, Columbia, and several smaller communities in the basin. The number of customer connections increased about 13 percent from 1980 to 1990. During 1989, 93 percent $(18.9 \mathrm{Mgal} / \mathrm{d})$ of the total municipal withdrawals were from the Duck River; was the source of about 20 percent $(3.83 \mathrm{Mgal} / \mathrm{d})$ of the surface water supplied. Residential uses were about 41 percent $(8.36 \mathrm{Mgal} / \mathrm{d})$ of the total; commercial about 10 percent $(2.02 \mathrm{Mgal} / \mathrm{d})$; and industrial about 28 percent $(5.64 \mathrm{Mgal} / \mathrm{d})$. Other uses, including losses, were about 22 percent $(4.40 \mathrm{Mgal} / \mathrm{d})$. Water use varies seasonally. During a drought year, summer 
water usage in the Maury WSA increased 21 percent over that of winter.

Low flows in the Duck River are augmented by releases from Normandy Reservoir. Winter low flows at Shelbyville are currently (1992) maintained at $77.6 \mathrm{Mgal} / \mathrm{d}$; summer low flows at $100 \mathrm{Mgal} / \mathrm{d}$. Discharges from the reservoir have been augmented since 1976 to maintain minimum flows, provide additional supplies, and enhance water quality. The 3Q20 discharge value changed from $34.8 \mathrm{Mgal} / \mathrm{d}$ to $46.1 \mathrm{Mgal} / \mathrm{d}$ at Shelbyville since regulation. At Columbia, the $3 \mathrm{Q} 20$ changed from $9.8 \mathrm{Mgal} / \mathrm{d}$ to $61.7 \mathrm{Mgal} / \mathrm{d}$.

The potential for developing ground-water resources as an important component of the water supply is uncertain because data are insufficient to make a thorough assessment. The geology of the area is complex, with lack of homogeneity among the rocks underlying the area. Limestones of Mississippian and Ordovician age are the principal rocks, with residuum deposits in some areas. Yields to wells in the area vary significantly, ranging from $<1$ to as high as $860 \mathrm{gal} / \mathrm{min}$. The most productive wells are located in Coffee County, in limestone rocks within the Highland Rim physiographic region. Analysis of well data indicates that 75 percent of these wells yield less than 30 gallons per minute. Two seepage investigations in subbasins to the Duck River indicate that local areas have potential for increased development of groundwater supplies, but additional testing and drilling would be required.

Projected future water demands in the basin were estimated with the IWR-MAIN System. The system uses a series of socioeconomic water-use algorithms to provide projections of future water demands. The model was calibrated to conditions as of 1989 and used to estimate water demands for the years 1995, 2000, and 2015.

Results from the water-use model projections indicate that water demands for the year 1995 would increase to $24.3 \mathrm{Mgal} / \mathrm{d}$ (19 percent); 2000 , to $28.3 \mathrm{Mgal} / \mathrm{d}$ (39 percent); and 2015, to $39.0 \mathrm{Mgal} / \mathrm{d}$ (91 percent). For year 2015 , residential water demand could increase by 122 percent; industrial water demand, by 93 percent; and commercial water demand, by 82 percent. The Maury WSA would have the largest increases in industrial and commercial water demands; the Bedford WSA, the largest increases in residential water demand.

Increases in withdrawals from the Duck River throughout the basin would reduce minimum flows at key sites along the river. The reductions would increase through the year 2015. For an operational flow of $155 \mathrm{ft}^{3} / \mathrm{s}(100.2 \mathrm{Mgal} / \mathrm{d})$ at Shelbyville, flow at Columbia at year 2015 would be $119 \mathrm{ft}^{3} / \mathrm{s}$ (76.8 Mgal/d). A further reduction to about $83.7 \mathrm{ft}^{3} / \mathrm{s}$ $(54.1 \mathrm{Mgal} / \mathrm{d})$ would occur at Columbia for a lower operational flow at Shelbyville of about $120 \mathrm{ft}^{3} / \mathrm{s}$ (77.6 Mgal/d).

\section{SELECTED REFERENCES}

Alexander, F.M., Keck, L.A., Conn, L.G., and Wentz, S.J., 1984, Drought-related impacts on municipal and major self-supplied industrial water withdrawals in Tennessee--Part B: U.S. Geological Survey WaterResources Investigations Report 84-4074, 398 p.

Bingham, R.H., 1985, Low flows and flow duration of Tennessee streams through 1981: U.S. Geological Survey Water-Resources Investigations Report 84-4347, $325 \mathrm{p}$.

Boland, J.J., Dziegielewski, B., Baumann, D.D., and Opitz, E.M., 1984, Influence of price and rate structures on municipal and industrial water use: Fort Belvoir, Virginia, U.S. Army Corps of Engineers Institute for Water Resources, Contract Report 84-Industrial Water Use: Fort Belvoir, Virginia, U.S. Army Corps of Engineers Institute for Water Resources, Contract Report 84-c-2, 187 p.

Brahana, J.V., and Hollyday, E.F., 1988, Dry stream reaches in carbonate terranes--surface indicators of ground-water reservoirs: Water Resouces Bulletin, v. 24 , no. 3, 577-580 p.

Burchett, C.R., 1977, Water resources of the upper Duck River Basin, Central Tennessee: Tennessee Department of Conservation, Division of Water Resources, $103 \mathrm{p}$. Flohr, D.F., Counts, P.H., Edwards, F.D., and Garrett, J.W., 1991 Water resources data, Tennessee, Water year 1990: U.S. Geological Survey Water Data Report TN-90-1, 260 p. 
Howe, C.W., and Linaweaver, F.P., Jr., 1967, The impact of price on residential water demand and its relation to system design and price structure: Water Resources Research v. 3, p. 12-32.

Kindler, J., and Russell, C.S., 1984, Modelling water demands: Orlando, Florida, Academic Press (Harcourt, Brace, Jovanovich, Inc), 248 p.

Lowery, J.F., Counts, P.H., Edmiston, H.L., and Edwards, F.D., 1983, Water resources data, Tennessee, water year 1983: U.S. Geological Survey Water Data Report TN-83-1, 327 p.

1987, Water resources data, Tennessee, water year 1987: U.S. Geological Survey Water Data Report TN-87-1, 438 p.

1988, Water resources data, Tennessee, water year 1988: U.S. Geological Survey Water Data Report TN-88-1, 382 p.

1989, Water resources data, Tennessee, water year 1989: U.S. Geological Survey Water Data Report TN-89-1, 266 p.

Miller, R.A., 1974, The geologic history of Tennessee: Tennessee Department of Conservation, Division of Geology, 69 p.

Tennessee Department of Economic and Community Development, 1988, Tennessee community data, Chapel Hill, Tennessee: January 1988, 4 p. pamphlet 1989a, Tennessee community data, Spring Hill, Tennessee: March 1989, 4 p. pamphlet. 1989b, Tennessee community data, Mt. Pleasant, Tennessee: March 1989, a p. pamphlet.

1989c, Tennessee community data, Lewisburg, Tennessee: August 1989, 4 p. pamphlet. 1990, Tennessee community data, Columbia, Tennessee: February 1990, 4 p. pamphlet.

Tennessee Department of Employment Security, 1990, Annual averages Tennessee labor force estimates 1985-1989: Nashville, Tennessee, Labor Market Information Unit, Research and Statistics Division, Tennessee Department of Employment Security, 87 p.

1991, Annual averages labor force and nonagricultural employment estimates 1986-1990: Nashville,
Tennessee, Labor Market Information Unit, Research and Statistics Division, Tennessee Department of Employment Security, 87 p.

U.S. Army Corps of Engineers, 1988, IWR-MAIN water use forecasting system, Version 5.1: Fort Belvoir, Virginia, Water Resources Support Center, Institute for Water Resources, 324 p.

U.S. Department of Commerce, 1982a, 1980 Census of Housing, General Housing Characteristics Tennessee: U.S. Government Printing Office, 253 p. 1982b, 1980 Census of Population, General Population Characteristics Tennessee: U.S. Government Printing Office, $245 \mathrm{p}$.

1983, 1980 Census of Housing, Detailed Housing Characteristics Tennessee: U.S. Government Printing Office, 202 p.

1988, County and city data book 1988: A statistical abstract supplement, $797 \mathrm{p}$.

1989, Climatological data annual summary Tennessee 1988: Asheville, North Carolina, National Oceanic and Atmospheric Administration, 17 p.

1990, Climatological data annual summary Tennessee 1989: Asheville, North Carolina, National Oceanic and Atmospheric Administration, $17 \mathrm{p}$.

U.S. Office of Management and Budget, 1987, Standard industrial classification manual 1987: Office of Management and Budget, 705 p.

University of Tennessee, Center for Business and Economic Research, College of Business Administration, 1990, An economic report to the Governor of the State of Tennessee on the State's economic outlook: Nashville, Tennessee, Tennessee State Planning Office, 196 p.

Vickers, B.B., ed., 1989, Tennessee statistical abstract 1989, Center for Business and Economic Research: Knoxville, Tennessee, University of Tennessee, 774 p. 1990, Tennessee statistical abstract 1990, Center for Business and Economic Research: Knoxville, Tennessee, University of Tennessee, $755 \mathrm{p}$.

White, J.L., ed., 1989, 1989 Directory of Tennessee Manufacturers, Geographic section: Nashville, Tennessee, M. Lee Smith Publishers \& Printers, p. B1-B309. 


\section{GLOSSARY}

Significant terms defined according to their meaning in this report are listed below:

Bill difference-the difference in the customer's actual total bill and what would be charged if all units of water were sold at the marginal price (U.S. Army Corps of Engineers, 1988).

Coefficient-statistically derived measure of a property or characteristic of water use used as a factor in the computation of water demand.

Constant--y-intercept in the demand models related to gallons per housing unit per day (U.S. Army Corps of Engineers, 1988).

Constant dollars--current dollar figures reflect actual prices or costs prevailing during the specified year(s). Constant dollar figures are estimates representing an effort to remove the effects of price changes from statistical series reported in dollar terms. Constant dollar series are derived by dividing current dollar estimates by the appropriate price index for the appropriate period of time. The result is presumably a series that would exist if prices were the same throughout time (Vickers, 1989).

Housing density--number of housing units per acre (U.S. Army Corps of Engineers, 1988).

Marginal price--price paid for water at the margin (U.S. Army Corps of Engineers, 1988).

Median income--type of average which divides the distribution into two equal parts; one-half of the households fall below the median income and one-half of the households exceed the median income (U.S. Department of Commerce, 1982).

Multiple-coefficient demand models--includes the price of water to the user, as well as related economic factors such as income, among the explanatory variables. Demand models are usually constructed according to econometric methods, where the structure of the model and the list of potential explanatory variables reflect assumptions regarding causality rather than simply arising from observed correlation (U.S. Army Corps of Engineers, 1988).
Municipal water-public-supply water delivered to residential, commercial, and industrial users. The amount of water also includes public/unaccounted water.

Per capita income--average annual rate of income per person.

Per capita water use--average daily rate of use of water per person.

Price elasticity-a dimensionless measure of the relation between a percent change in water use and a percent change in price when other factors affecting water demand remain unchanged. The same concept may be applied to express the responsiveness of water use to changes in other variables (Boland and others, 1984).

Public/unaccounted sector--free-service water and distribution losses which include leakage, pipe flushing, and apparent losses caused by cumulative meter misregistration.

Single-coefficient (or multiple-coefficient) requirement models--estimate water use as a product of projected service area population and a projected value of per capita use. It can be expressed as a function of one or more explanatory variables. The models do not include the price of water, or other economic factors, as an explanatory variable. The models imply that water use is an absolute requirement, unaffected by economic choice (U.S. Army Corps of Engineers, 1988).

Standard Industrial Classification (SIC)-the statistical classification standard underlying all establishment-based Federal economic statistics classified by industry. The SIC is used to promote the comparability of establishment data describing various facets of the U.S. economy. The classification covers the entire field of economic activities and defines industries in accordance with the structure and composition of the economy (Office of Management and Budget, 1987).

Water demand--relation between water use and price, when all other factors are held constant. Demand is a negative functional relation; increased price results in decreased water use (Boland and others, 1984).

Water use--measured or estimated offstream withdrawals of water and return flows. 
APPENDIXES

- PAGE 37 FOLLOWS- 


\section{APPENDIX A. CALCULATION OF BILL DIFFERENCE EXPRESSED IN 1980 CONSTANT DOLLARS}

[ $>$, greater than; bill difference, the difference in the consumer's actual total bill and what would be charged if all units of water were sold at the margin (marginal price)]

\begin{tabular}{|c|c|c|}
\hline $\begin{array}{l}\text { Use, } \\
\text { in gallons }\end{array}$ & $\begin{array}{c}\text { Rate structure } \\
\text { Cost of } \\
\text { water service, } \\
\text { in dollars per } \\
1,000 \text { gallons }\end{array}$ & $\begin{array}{c}\text { Cost of } \\
\text { waste service, } \\
\text { in dollars per } \\
1,000 \text { gallons }\end{array}$ \\
\hline $0-50,000$ & 0.50 & 1.30 \\
\hline $50-250,000$ & .38 & 1.30 \\
\hline$>250,000$ & .35 & 1.30 \\
\hline Service charge & 2.50 & 3.50 \\
\hline $\begin{array}{l}\text { Annual price per } \\
1,000 \text { gallons. }\end{array}$ & 1.80 & \\
\hline $\begin{array}{l}\text { Marginal price per } \\
1,000 \text { gallons. }\end{array}$ & 1.65 & \\
\hline
\end{tabular}

Water use

\begin{tabular}{lcc} 
Billing period & $\begin{array}{c}\text { Gallons per day } \\
\text { per housing unit }\end{array}$ & $\begin{array}{c}\text { Gallons per month } \\
\text { per housing unit }\end{array}$ \\
\hline 1 month & 168 & 5,040
\end{tabular}

Biil difference calculation

\begin{tabular}{lcc} 
Bill difference & $\begin{array}{c}\text { Cost of } \\
\text { water sorvice, } \\
\text { in dollars }\end{array}$ & $\begin{array}{c}\text { Cost of } \\
\text { waste service } \\
\text { in dollars }\end{array}$ \\
\hline $\begin{array}{l}\text { Service charge } \\
\begin{array}{l}\text { Average monthly cost } \\
\text { per housing unit. }\end{array}\end{array}$ & 2.50 & 3.50 \\
Bill & 2.52 & 6.55 \\
\hline
\end{tabular}

Total water and sewer bill

Less price paid at the margin

15.07

8.32

Equals annual bill difference

Equals annual bill difference

(in 1980 dollars).
6.75

4.25 


\section{APPENDIX B. POPULATION PROJECTIONS AND NUMBER OF OCCUPIED HOUSING UNITS}

IWSA, Water-service area; a, U.S. Census Bureau; b, University of Tennessee; $c, y=e^{k} ; y$, population; $e$, base of the natural

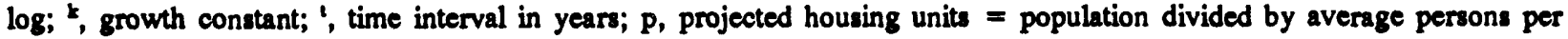
household]

\begin{tabular}{|c|c|c|c|c|}
\hline Year & $\begin{array}{l}\text { Average persons } \\
\text { per household }\end{array}$ & Year & Population & Housing units \\
\hline \multicolumn{5}{|c|}{ Bedford WSA } \\
\hline $\begin{array}{l}1980 \\
1990\end{array}$ & $\begin{array}{l}2.81 \mathrm{a} \\
2.53 \mathrm{a}\end{array}$ & $\begin{array}{l}1980 \\
1985 \\
1989 \\
1990 \\
1995 \\
2000 \\
2015\end{array}$ & $\begin{array}{l}27,976 \mathrm{a} \\
28,700 \mathrm{~b} \\
30,157 \mathrm{~b} \\
30,411 \mathrm{a} \\
31,705 \mathrm{c} \\
33,056 \mathrm{c} \\
37,462 \mathrm{c}\end{array}$ & $\begin{array}{r}9,943 \\
10,992 \\
11,940 \\
12,041 \\
12,553 \mathrm{p} \\
13,088 \mathrm{p} \\
14,833 \mathrm{p}\end{array}$ \\
\hline \multicolumn{5}{|c|}{ Coffee WSA } \\
\hline $\begin{array}{l}1980 \\
1990\end{array}$ & $\begin{array}{l}2.81 a \\
2.44 a\end{array}$ & $\begin{array}{l}1980 \\
1985 \\
1989 \\
1990 \\
1995 \\
2000 \\
2015\end{array}$ & $\begin{array}{l}38,311 \mathrm{a} \\
40,600 \mathrm{~b} \\
40,130 \mathrm{~b} \\
40,339 \mathrm{a} \\
41,391 \mathrm{c} \\
42,472 \mathrm{c} \\
45,886 \mathrm{c}\end{array}$ & $\begin{array}{l}13,649 \\
15,084 \\
16,433 \\
16,519 \\
16,950 \mathrm{p} \\
17,392 \mathrm{p} \\
18,791 \mathrm{p}\end{array}$ \\
\hline \multicolumn{5}{|c|}{ Marshall WSA } \\
\hline $\begin{array}{l}1980 \\
1990\end{array}$ & $\begin{array}{l}2.76 \mathrm{a} \\
2.48 \mathrm{a}\end{array}$ & $\begin{array}{l}1980 \\
1985 \\
1989 \\
1990 \\
1995 \\
2000 \\
2015\end{array}$ & $\begin{array}{l}19,742 a \\
20,600 \mathrm{~b} \\
21,029 \mathrm{~b} \\
21,539 \mathrm{a} \\
22,498 \mathrm{c} \\
23,499 \mathrm{c} \\
26,778 \mathrm{c}\end{array}$ & $\begin{array}{r}7,144 \\
7,923 \\
8,495 \\
8,701 \\
9,088 p \\
9,493 p \\
10,817 p\end{array}$ \\
\hline \multicolumn{5}{|c|}{ Maury WSA } \\
\hline $\begin{array}{l}1980 \\
1990\end{array}$ & $\begin{array}{l}2.44 a \\
2.48 a\end{array}$ & $\begin{array}{l}1980 \\
1985 \\
1989 \\
1990 \\
1995 \\
2000 \\
2015\end{array}$ & $\begin{array}{l}51,095 \mathrm{a} \\
52,900 \mathrm{~b} \\
54,426 \mathrm{~b} \\
54,812 \mathrm{a} \\
56,767 \mathrm{c} \\
58,794 \mathrm{c} \\
65,321 \mathrm{c}\end{array}$ & $\begin{array}{l}20,902 \\
22,286 \\
21,934 \\
22,090 \\
22,878 p \\
23,695 p \\
26,325 p\end{array}$ \\
\hline
\end{tabular}




\section{APPENDIX C.--REGRESSION ANALYSIS FOR EMPLOYMENT PROJECTIONS}

[WSA, water service area; $m$, model input; a, adjusted estimate; Stdev. Coef., standard deviation of the coefficient, that is, the estimated coefficient has an approximately normal distribution and it is the measure of variability of sample of the coefficient; variability in the sample; R-square, measure of the total variability in the dependent variable]

\begin{tabular}{lllll}
\hline & \multicolumn{3}{c}{ Water-service area } \\
\cline { 2 - 4 } YEAR & Bedford & Coffee & Marshall & Maury \\
\hline 1980 & 9,780 & 16,580 & 7,360 & 17,320 \\
1981 & 9,180 & 16,960 & 7,430 & 17,100 \\
1982 & 7,637 & 15,505 & 7,692 & 15,396 \\
1983 & 7,788 & 15,170 & 7,365 & 15,150 \\
1984 & 8,687 & 16,463 & 8,879 & 16,509 \\
1985 & 9,034 & 16,947 & 8,127 & 16,645 \\
1986 & 9,233 & 17,772 & 7,760 & 17,827 \\
1987 & 10,094 & 18,243 & 8,423 & 18,157 \\
1988 & 10,942 & 18,510 & 8,972 & 18,865 \\
1989 & 11,115 & 18,947 & 9,450 & 22,457 \\
1990 & 11,380 & 18,320 & 10,250 & 23,630 \\
$1995 \mathrm{~m}$ & 12,333 & 20,229 & 11,006 & $24,527 \mathrm{a}$ \\
$2000 \mathrm{~m}$ & 13,733 & 21,734 & 12,386 & $27,742 \mathrm{a}$ \\
$2015 \mathrm{~m}$ & 17,933 & 26,249 & 16,526 & $37,387 \mathrm{a}$ \\
\hline & & & & \\
\hline
\end{tabular}

Regression analysis

\begin{tabular}{lccccc}
\cline { 2 - 5 } WSA & Constant & $\begin{array}{c}\text { Stdev. } \\
\text { Coef. }\end{array}$ & Coefficient & $\begin{array}{c}\text { Stdev. } \\
\text { Coef. }\end{array}$ & $\begin{array}{c}\text { R-square } \\
\text { percent }\end{array}$ \\
\hline Bedford & 7,853 & 589 & 280 & 86.7 & 53.6 \\
Coffee & 15,413 & 506 & 301 & 74.6 & 64.4 \\
Marshall & 6,590 & 369 & 276 & 54.4 & 74.1 \\
Maury & 14,503 & 982 & 605 & 145 & 66.0 \\
\hline
\end{tabular}

